\title{
Climatic structures and intensities of the last two glacials documented by terrestrial mollusks from Chinese loess sequences
}

\author{
DAN ZHANG, NAI-QIN WU, FENG-JIANG LI, DENIS-DIDIER ROUSSEAU, XIAO-YUN CHEN,
} YA-JIE DONG AND HOU-YUAN LU

\author{
Zhang, D., Wu, N.-Q., Li F.-J., Rousseau, D.-D., Chen, X.-Y., Dong, Y.-J. \& Lu, H.-Y.: Climatic \\ structures and intensities of the last two glacials documented by terrestrial mollusks from Chinese loess \\ sequences.
}

Knowledge of the structures and intensities of past glaciations is crucial for understanding Quaternary palaeoclimatic evolution. Terrestrial mollusks are a reliable proxy of past environmental conditions and can provide specific climatic insights into glacials. Here we compare the climatic evolution of the last two glacials, based on mollusk fossils from the L2 and L1 loess units (equivalent to marine isotopic stages (MIS) 6 and 4-2, respectively) of the Xifeng and Luochuan sections of the Chinese Loess Plateau (CLP). The results show that both glacials had a tripartite structure but with different intensities, as indicated by variations in the abundance of the dominant cold-aridiphilous mollusk species, Vallonia tenera and Pupilla aeoli. The first stage, from $\sim 191$ to 184 ka for MIS 6, and from $\sim 71$ to $57 \mathrm{ka}$ for MIS 4, was characterized by a cold, arid climate, as indicated by the abundance of $V$. tenera and $P$. aeoli, and the limited occurrence of thermo-humidiphilous (TH) species. The second stage, from $\sim 184$ to $155 \mathrm{ka}$ for MIS 6, and from $\sim 57$ to $29 \mathrm{ka}$ for MIS 3, was characterized by a relatively mild, humid climate, reflected by a decrease in $V$. tenera and $P$. aeoli, and an increase in $\mathrm{TH}$ species. The last stage, from $\sim 155$ to $130 \mathrm{ka}$ for MIS 6, and from $\sim 29$ to $11.7 \mathrm{ka}$ for MIS 2, experienced the coldest and driest conditions, as indicated by the dominance of $V$. tenera and P. aeoli in late MIS 6 and by the reduced occurrence of the grassland biomass, necessary for the growth of CA species, in MIS 2. The climate during MIS 2 was much colder and drier than that during late MIS 6 . We suggest that the structures of the glacials were controlled mainly by insolation driven by changing astronomical configurations, among which obliquity likely played the major role. The different glacial intensities across the CLP may also have been related to variations in Northern Hemisphere ice sheets and the temperature of the tropical oceans. 
Dan Zhang, Nai-Qin Wu (e-mail: nqwu@mail.iggcas.ac.cn), Feng-Jiang Li, Ya-Jie Dong and Hou-Yuan Lu, Key Laboratory of Cenozoic Geology and Environment, Institute of Geology and Geophysics, Chinese Academy of Sciences, Beijing 100029, China; Dan Zhang, Nai-Qin Wu and Hou-Yuan Lu, College of Earth Sciences, University of Chinese Academy of Sciences, Beijing 100049, China; Nai-Qin Wu and Feng-Jiang Li, Innovation Academy for Earth Science, Chinese Academy of Sciences, Beijing 100029, China; Feng-Jiang Li, Center for Excellence in Life and Paleoenvironment, Chinese Academy of Sciences, Beijing 100044, China; Denis-Didier Rousseau, Ecole Normale Supérieure, Laboratoire de Météorologie Dynamique, UMR CNRS 8539, Paris 75231, France; Lamont Doherty Earth Observatory of Columbia University, New York 10964, USA; Xiao-Yun Chen, Geological Museum of China, Beijing 100034, China; Hou-Yuan Lu, Center for Excellence in Tibetan Plateau Earth System Science, Chinese Academy of Sciences, Beijing 100101, China. 
The climate of the Quaternary period was characterized by the alternation of long, cold glacials and short, warm interglacials (Hays et al. 1976; Shackleton et al. 1984; Lang \& Wolff 2011). Understanding the characteristics of different glacials is crucial for reconstructing the Quaternary climatic history and for exploring the driving mechanisms of the glacial-interglacial cycles. In recent years, numerous studies have focused on glacial climatic variations at orbital and millennial timescales based on the study of marine, ice, and terrestrial (lake, loess, and speleothem) deposits (Hays et al. 1976; Dansgaard et al. 1993; Liu \& Ding 1993; Porter \& An 1995; Petit et al. 1999; Cheng et al. 2016). However, because most studies have focused on glacial inceptions and terminations, as well as on abrupt climatic changes during glacials, the climatic structures and intensities of different glacials remain poorly investigated.

The loess records from the Chinese Loess Plateau (CLP) of north-central China are of particular value for investigating the structure and intensity of past glacials, and they have been used as evidence in several important studies of the climatic variations of glacial cycles. Magnetic susceptibility (Kukla \& An 1989; An et al. 1991a) and chemical weathering indexes (Liu \& Ding 1993; Guo et al. 1998) have been widely used to document the effects of changing summer monsoon intensity, while the grain-size record has been found to reflect the winter monsoon intensity (An et al. 1991b; Ding et al. 1995) and high-frequency climatic oscillations (Porter \& An 1995; Ding et al. 1999). The carbon and oxygen isotopic ratios in carbonate concretions from loess and palaeosol sequences have been used to characterize variations in pedogenic intensity (Han et al. 1997; Liu \& Ding 1993). Additionally, mollusk assemblages have been regarded as reliable biological proxies that enable the interpretation of past environmental conditions (Wu et al. 1996, 1997, 1999; Rousseau \& Wu 1997, 1999).

Terrestrial mollusks are climatically sensitive and they are the only abundant biological remains available for reconstructing the climatic variations preserved in European (Ložek 1964, 1990; Rousseau 1985; Rousseau \& Puisségur 1990), Chinese (Liu 1985; Wu et al. 1996, 1997, 1999, 2000) and North American loess deposits (Rousseau \& Kukla 1994; Rossignol et al. 2004). Terrestrial mollusks are generally well-preserved in loess units, with shell dissolution occurring rarely - especially in Chinese loess units - due to weak carbonate leaching and palaeosol development during glacials. This is especially true for fossil records from the thick upper loess layers of the L2 and L1 units across the CLP, which are the equivalents of marine isotopic stages (MIS) 6 and 4-2, respectively. These thick loess layers can provide detailed palaeoenvironmental information which enables us to determine 
the climatic structures and intensities of the corresponding glacials. In previous studies, Wu et al. (1996, 1997, 1999, 2000) and Rousseau \& Wu (1997, 1999) presented high-resolution records of mollusk assemblages in Chinese loess sequences. Such records have been used to reconstruct short-term climatic instability (Wu et al. 1999, 2002), long-term evolution of summer and winter palaeo-monsoons (Wu et al. 1996, 2006, 2007; Li et al. 2006, 2008; Wu \& Wu 2011), and their potential relationships with orbital forcing ( $\mathrm{Wu}$ et al. 2000, 2001; Li \& Wu 2010). However, distinctions in the climatic structures and intensities of different glacials themselves have not been investigated in detail.

Here we present a new record of terrestrial mollusks from the L2 and L1 loess units of the Xifeng section in the central CLP, which is combined with an equivalent record from the Luochuan section (Wu et al. 1996, 1997, 1999, 2000; Rousseau \& Wu 1997, 1999), with the aim of investigating the climatic variability of the last two glacials.

\section{Geographical background and site description}

Loess-palaeosol sequences are extensively distributed in the CLP and alternations of the loess and palaeosol layers in the CLP are well correlated with the marine oxygen isotope record, with loess layers developed during glacials and palaeosols mainly during interglacials (Liu 1985; Kukla 1987). The Xifeng $\left(35^{\circ} 46^{\prime} \mathrm{N}, 107^{\circ} 41^{\prime} \mathrm{E}\right)$ and Luochuan $\left(35^{\circ} 45^{\prime} \mathrm{N}, 109^{\circ} 25^{\prime} \mathrm{E}\right)$ sections, in the central CLP (Fig. 1), are regarded as representative loess sequences for studying Quaternary climatic variations (e.g. Liu 1985; Kukla 1987; Kukla \& An 1989; Wu et al. 1996, 1999; Rousseau \& Wu 1997; Guo et al. 1998; Hao et al. 2012). The modern climate of the CLP is influenced by the East Asian monsoon and is characterized by in-phase variations in temperature and precipitation. The monsoon carries warm, moist air to the CLP during the summer, which results in heavy rainfall. During the winter, monsoon winds from the Siberian High prevail over the CLP, resulting in a dry, cold climate (Ding et al. 1995, $1999,2002)$. The Xifeng section is $\sim 160 \mathrm{~km}$ west of the Luochuan section.

The complete sequences of the Xifeng and Luochuan sections are $\sim 176 \mathrm{~m}$ and $\sim 137 \mathrm{~m}$ in thickness, respectively (Liu 1985; Kukla \& An 1989). The thicknesses of the L2 and L1 units are $\sim 6 \mathrm{~m}$ and $\sim 10 \mathrm{~m}$ in Xifeng, and $\sim 5 \mathrm{~m}$ and $\sim 8.5 \mathrm{~m}$ in Luochuan (Fig. 2). These two units were deposited during the last two glacials (Liu 1985; Kukla 1987) and correspond to MIS 6 ( 191-130 ka) and MIS 4-2 ( 71-11.7 ka) (Kukla 1987; Ding et al. 2002) (Fig. 2). 
104

105

106

107

108

109

110

111

112

113

114

115

116

117

118

119

120

121

122

124

125

126

127

128

129

130

\section{Materials and methods}

A total of 164 mollusk fossil assemblages were analyzed at 10-cm intervals from the L2 and L1 loess units of the Xifeng section (Table S1). Each sample weighed $\sim 15 \mathrm{~kg}$. Parallel to the mollusk samples, we measured the low-field magnetic susceptibility every $10 \mathrm{~cm}$ using a portable Bartington magnetic susceptibility meter. All mollusk samples were washed and sieved with a mesh diameter of $0.5 \mathrm{~mm}$ in the field, and the mollusk shells were further sieved and dried in air. Subsequently, in the laboratory, all mollusk fossils were picked out and identified under a binocular microscope. All identifiable remains (whole shells and shell fragments) were considered in the total count of individuals following the method of Puisségur (1976). The abundance of each species was expressed as the number of individuals of that species per $15 \mathrm{~kg}$ of sediment. For the Luochuan section, 140 fossil snail assemblages (Table S1) were analyzed using the same method, as described in Wu et al. (1996, 1999, 2000) and Rousseau \& Wu (1997, 1999).

The uniformity of the stratigraphy of the loess deposits over hundreds of kilometers across the CLP enabled us to apply a previously published chronology to our mollusk sequences (e.g. Liu 1985; Kukla \& An 1989; Ding et al. 2002; Hao et al. 2012). The chronology of the Xifeng and Luochuan mollusk sequences was established using the correlations between our measured magnetic susceptibility records and the recently published grain-size timescales of the Xifeng and Luochuan sections (Hao et al. 2012) (Fig. 2, Table 1). Key age control points (Table 1) were defined by comparing our magnetic susceptibility records with those of Hao et al. (2012).

Vallonia tenera and Pupilla aeoli are dominant cold-aridiphilous (CA) species in the fossil snail assemblages in the CLP (Wu et al. 1996, 1999, 2000, 2001, 2002; Rousseau \& Wu 1997, 1999). These species prefer a relatively cold and arid environment, such as steppe and desert steppe (Wu et al. 2018). In previous studies, the two species were commonly regarded as a proxy for the strength of the winter monsoon (Wu et al. 1996, 1999, 2000, 2001, 2002, 2006; Li et al. 2006, 2008; Wu \& Wu 2011), and their abundance generally varies in parallel with global palaeoclimate curves reconstructed for the associated marine isotopic stages (Fig. 2). Therefore, we used the abundances of the two species to reconstruct past variations in the structure and intensity of glacials in the CLP. 


\section{Results}

\section{Fossil mollusk assemblages}

Mollusks were abundant in the L2 and L1 loess units of the Xifeng and Luochuan sections; the average shell concentrations were 220/15 kg and 206/15 kg, respectively. In the Xifeng section, 15 species were identified from the L2 and L1 loess layers, and 23 species were identified in the Luochuan section. Identifications were based on previously archived specimens and on the monographs of Yen (1939), Chen \& Gao (1987), and Nekola et al. (2015). The principal species are shown in Fig. 3. As in previous studies (Liu 1985; Wu et al. 1996, 1999, 2000, 2001, 2002, 2007, 2018; Dong et al. 2019), the mollusk species (Table 2) were subdivided into three ecological groups: cold-aridiphilous (CA), cool-humidiphilous (CH), and thermo-humidiphilous (TH).

The CA group comprises Vallonia tenera, Pupilla aeoli, Pupilla cf. muscorum, Cathaica pulveraticula, Cathaica pulveratrix, Cathaica richthofen, and Cathaica sp.. The CH group comprises a single species, Vallonia cf. pulchella. The TH group comprises Gastrocopta armigerella, Gastrocopta coreana, Gastrocopta sp., Punctum orphana, Metodontia yantaiensis, Metodontia huaiensis, Metodontia beresowskii, Metodontia sp., Succinea sp., Kaliella lamprocystis, Kaliella sp., Macrochlamys angigyra, Opeas striatissimum, Trichochloritis sp., Vitrea pygmaea, Vertigo chenchiawoensis, and Limacidae.

Xifeng section. - As shown in Fig. 4A, the composition of the mollusk assemblages from L2 (MIS 6) exhibits a tripartite pattern, which is confirmed by the cluster analysis results. The CA species (e.g. $V$. tenera, $P$. aeoli and $P$. cf. muscorum species) are dominant, whereas species from the $\mathrm{CH}$ and $\mathrm{TH}$ groups are relatively rare. In the lower portion of L2 ( 191-184 ka), the number of individuals of the CA group increased rapidly to reach the maximum, from $\sim 800$ to $\sim 1600 / 15 \mathrm{~kg}$. Thereafter, during $\sim 184-155 \mathrm{ka}$, the number of individuals of the CA group decreased substantially to reach their lowest concentration of $\sim 80 / 15 \mathrm{~kg}$. A few species of the $\mathrm{CH}$ and $\mathrm{TH}$ groups appeared simultaneously, such as V. cf. pulchella, G. armigerella, P. orphana, and Succinea sp., mostly between $\sim 184$ and $160 \mathrm{ka}$. Finally, in the upper part of L2 ( 155-130 ka), the CA group increased again to reach a second maximum, $\sim 570 / 15 \mathrm{~kg}$; this interval is also characterized by the rarity of individuals of the TH group.

A tripartite division is also evident in L1 (Fig. 4A). In subunit L1-5 ( 71-57 ka), the CA group species (e.g. V. tenera, P. aeoli and P. cf. muscorum) were overwhelmingly dominant, and their 
composition was similar to that of the lower part of L2. In subunits L1-4, L1-3, and L1-2 ( 57-29 ka), individuals of the $\mathrm{CA}$ group decreased while those of the $\mathrm{CH}$ and $\mathrm{TH}$ groups reappeared, similar to the variations observed in the middle of L2. However, in subunit L1-1 ( $29-11.7 \mathrm{ka})$, the composition of the mollusk species differs substantially from that in the upper part of L2. Species of the CA and TH groups in L1-1 were extremely rare. Furthermore, the total concentration of individuals $(<50 / 15 \mathrm{~kg})$ in L1-1 reached the lowest level overall, and in contrast to the upper part of L2, high concentrations of the CA were not observed.

Luochuan section - The mollusk assemblages in the Luochuan section also reveal a tripartite structure in L2 (Fig. 4B), which is similar to that of the Xifeng section. In the lower part of L2 ( 191-184 ka), the predominant species are $V$. tenera and $P$. aeoli, and the CA-group increased rapidly to a high concentration $(\sim 800 / 15 \mathrm{~kg})$ during this period. The abundance of the CA group decreased in the middle part of L2 ( 184-155 ka), with a minimum concentration of $\sim 80 / 15 \mathrm{~kg}$, whereas the abundances of the TH and CH groups increased, from $\sim 70$ to $\sim 280 / 15 \mathrm{~kg}$. In the upper part of L2 $(\sim 155-130 \mathrm{ka})$, the abundance of the CA group increased to another peak $(\sim 580 / 15 \mathrm{~kg})$, accompanied by the decreasing representation of the TH group.

The variations in the fossil mollusk species of $\mathrm{L} 1$ in the Luochuan section also exhibit a tripartite structure (Fig. 4B). In subunit L1-5 ( 71-57 ka), the composition of the snail assemblage shows a similar pattern of variations to that of the lower part of L2, which is also dominated by species of the CA group. The CA group also decreased in subunits L1-4, L1-3 and L1-2 ( $\sim 57-29 \mathrm{ka})$, whereas the species of the $\mathrm{CH}$ and $\mathrm{TH}$ groups both exhibit similar trends to those of the middle part of L2. A major difference is evident between subunit L1-1 ( 29-11.7 ka) and the upper part of L2: species of the CA and TH groups were both extremely rare in subunit L1-1, whereas those of the CA group did not reach higher values in the upper part of L2.

Units L2 and L1 of the Xifeng and Luochuan sections therefore show a similar trend of variation of their fossil snail records over time. However, there were slight differences in species composition between the two sections during the two glacials. First, the Xifeng section yielded a significant proportion of the CA species $P$. cf. muscorum (Fig. 4A, B), whereas this species is poorly represented in the Luochuan sequence. Second, the species compositions of the Xifeng and Luochuan sections are different: the Xifeng section is characterized by G. coreana and K. lamprocystis, whereas the Luochuan section is characterized by C. pulveraticula, C. richthofen, Gastrocopta sp., M. beresowskii, $O$. 
striatissimum, Kaliella sp., Trichochloritis sp., V. pygmaea, V. chenchiawoensis, and Limacidae. In summary, despite minor variations in the mollusk assemblage composition, both sequences are dominated by the CA group, and there is a low number of individuals of the TH group.

Variations in V. tenera and P. aeoli during MIS 6 and MIS 4-2

During the last two glacials, $V$. tenera and $P$. aeoli dominated the mollusk assemblages ( $>40-50 \%$ ); they have a similar ecological significance (Fig. 5). The variations in their total abundances are well correlated with the marine isotope stages (Figs 2,6), which reflects global glacial and interglacial climatic oscillations. In some intervals, such as early MIS 6 (191-184 ka) and MIS 4 (71-57 ka), both comprised more than $\sim 80 \%$ of the total number of individuals. Furthermore, the numbers of individuals of $V$. tenera and P. aeoli were also distributed continuously in units L2 and L1 units and they show the same pattern of temporal variation in both sequences (Fig. 6). Therefore, we reconstructed the pattern of climatic evolution of the last two glacials (i.e. their structure and intensity) based on the variations in the abundances of these two species.

During the early part of MIS $6(\sim 191-184 \mathrm{ka})$, the maximum concentration of the sum of $V$. tenera and $P$. aeoli in the Xifeng and Luochuan sections reached $\sim 1200 / 15 \mathrm{~kg}$ (representing $\sim 90 \%$ of all species) and $\sim 800 / 15 \mathrm{~kg}$ (representing $\sim 95 \%$ of all species), respectively (Fig. 6). This interval is also characterized by the presence of several TH members, such as the genus Metodontia (Fig. 4). Subsequently, during $\sim 184-155 \mathrm{ka}$, the concentrations of $V$. tenera and $P$. aeoli in both sections decreased rapidly to a minimum of $\sim 60 / 15 \mathrm{~kg}$, representing $\sim 70 \%$ of the individuals of all species in the Xifeng section and $\sim 30 \%$ in the Luochuan section. In addition, TH species were better represented, including G. armigerella, P. orphana, Limacidae, and the genus Metodontia (Fig. 4). In the final stage of MIS $6(\sim 155-130 \mathrm{ka})$, the total number of $V$. tenera and $P$. aeoli increased again and reached $\sim 520 / 15 \mathrm{~kg}$ in the Xifeng section (representing $\sim 90 \%$ of all species), and $\sim 560 / 15 \mathrm{~kg}$ in the Luochuan section (representing $\sim 95 \%$ of the individuals of all species). However, the $\mathrm{CH}$ and $\mathrm{TH}$ groups in late MIS 6 were much less well-represented than in early MIS 6 (Fig. 4). Overall, the variations in $V$. tenera and $P$. aeoli during MIS 6 show similar trends to the pattern of global changes indicated by the marine isotope record (Fig. 6).

During MIS 4 ( 71-57 ka), the maximum concentration of $V$. tenera and P. aeoli occurred in both the Xifeng ( $\sim 350 / 15 \mathrm{~kg}$ ) and Luochuan sections ( $\sim 40 / 15 \mathrm{~kg}$ ) (Fig. 6), associated with a low number of individuals of TH species (Fig. 4). During this period, both the CA and TH groups were represented by 
a lower number of individuals than in early MIS 6 (Fig. 4). Subsequently, in MIS 3 ( $\sim 57-29$ ka), both

$V$. tenera and $P$. aeoli decreased at Xifeng $(\sim 20 / 15 \mathrm{~kg})$ and Luochuan $(\sim 50 / 15 \mathrm{~kg})$ representing $\sim 50 \%$ and $\sim 30 \%$ of the number of individuals of all species, respectively (Fig. 6); however, there was a significant increase in the counts of the TH species (Fig. 4), such as G. armigerella, G. coreana, P. orphana, Limacidae, and the genus Metodontia.

Finally, during MIS 2 ( 29-11.7 ka) (i.e. the Last Glacial Maximum, LGM), individuals of $V$. tenera and P. aeoli were extremely rare in both the Xifeng and Luochuan sections (Fig. 6), and the total number of the individuals of the CA and TH groups did not exceed 50/15 kg (Fig. 4). This interval is also characterized by low values of magnetic susceptibility, reflecting cold and dry environmental conditions (Fig. 4). The low number of mollusk individuals observed during this interval could not have been caused by intensive decalcification, which occurs as a result of intensive pedogenic processes associated with a warm and humid interglacial environment.

\section{Discussion}

As mentioned previously, the two studied loess sections, 160-km apart, yielded terrestrial mollusk assemblages dominated by species of the CA group during the last two glacials. Although there are slight differences in mollusk species composition in the two sections (Fig. 4), which may reflect local conditions, our records clearly document changes in the structure and intensity of the last two glacials on the orbital timescale.

\section{Structure of the last two glacials in the CLP}

The results (Figs 4,6) show that the last two glacials (MIS 6 and MIS 4-2) had similar climatic structures, consisting in both cases of two cold and dry intervals (the early and late stages) and a relatively mild and humid intervening stage. This tripartite structure documented by our snail records corresponds well to the global glacial structure revealed by sea level variations (Grant et al. 2014; Spratt \& Lisiecki 2016). Furthermore, these characteristics of glacials have also been documented elsewhere, in terrestrial (Rousseau 1991; Tzedakis et al. 2006; Hao et al. 2012), marine (Bühring et al. 2004; Raymo et al. 2004), and ice (Petit et al. 1999) records. In terrestrial records, magnetic susceptibility (Hao et al. 2012, 2015), organic carbon isotope composition $\left(\delta^{13} \mathrm{C}_{\mathrm{TOC}}\right)$, and the proportion of C4 plants (Zhou et al. 2016) from the CLP show higher values in the middle part of the last two glacials compared with the early and late stages. Moreover, mollusk assemblages (Rousseau 
1987, 1991) and tree pollen (Tzedakis et al. 2006) records from European loess sequences indicate that both the TH mollusk species and arboreal pollen were more abundant during the middle part of the last two glacials, whereas their abundances were very low during the early and late parts. This trend of development is almost parallel to that of the mollusk records from the CLP. In marine and ice sediments, such as the South China Sea (Bühring et al. 2004), North Atlantic (Raymo et al. 2004), and Antarctic ice cores (Petit et al. 1999), the oxygen isotopic records exhibit prominent negative $\delta^{18} \mathrm{O}$ excursions in the middle part of the last two glacials and positive values in the early and late parts.

\section{Intensity of the last two glacials in the CLP}

Our mollusk records show that the variations in glacial intensities within MIS 6 and MIS 4-2 were different. During MIS 6, the most intense stage occurred in the later part, the second strongest stage was in the early part, and a mild climatic stage occurred in the middle part. During the last glacial (MIS 4-2), the coldest and most arid climate occurred during MIS 2; in comparison, MIS 4 experienced less cold and arid conditions, whereas relatively mild and humid interstadial conditions prevailed during MIS 3.

The most prominent difference between the last two glacials is that the climatic conditions during MIS 2 were much colder and more arid than those during the late stage of MIS 6 . The extreme environment of MIS 2 reduced the extent of the grassland environment necessary for the growth of the CA species, resulting in a low total number of snail individuals (Fig. 4). A modern analog for the conditions of MIS 2 has been found in Yakutia (Horsák et al. 2013). The much colder and drier environment of MIS 2 in the CLP is also characterized by minima in organic carbon isotopes and of the proportion of C4 plants (Zhou et al. 2016), and the dominance of desert steppe (Jiang et al. 2014). MIS 2 is also characterized by a higher ratio of herbs and Pinus to total pollen in a record from the South China Sea (Sun et al. 2003), and by lower sea surface temperature (SST) in the South China Sea (Herbert et al. 2010), Pacific Ocean (Liu \& Herbert 2004), Indian Ocean (Herbert et al. 2010), and Atlantic Ocean (Lawrence et al. 2009). Rousseau (1991) also inferred colder temperatures during MIS 2 from mollusk assemblages in European loess deposits. The results of a climate simulation indicated that the atmospheric temperature of the Northern Hemisphere during MIS 2 was $\sim 1.2{ }^{\circ} \mathrm{C}$ lower than that during the late part of MIS 6 (Bintanja et al. 2005).

\section{Possible causes for structure and intensities of glacials in the CLP}


insolation variations driven by Earth orbital parameters, especially obliquity. The prominent increase in the abundance of $V$. tenera and $P$. aeoli in both the early and late stages of glacials (Fig. 6) corresponds approximately to periods of low obliquity (Fig. 7), and the decreases in their abundance in the middle stages of glacials correspond to intervals of higher obliquity (Fig. 7). These observations agree with the results of previous studies (Wu et al. 2000, 2001), which indicated that both the CA and TH mollusk groups are tightly coupled to variation in obliquity, with a period of $41 \mathrm{kyr}$.

Obliquity is an important factor controlling the latitudinal distribution of insolation (Milankovitch 1941). During the early and late stages of the last two glacials, low obliquity reduced the summer insolation at both northern high and middle latitudes and weakened the summer insolation gradient between middle and low latitudes (Fig. 7). At high latitudes, the reduction of northern summer insolation promoted ice sheet expansion, thereby enhancing the Asian winter monsoon which in turn resulted in the passage of cold, dry air across the CLP (Ding et al. 1995); and at mid-latitudes, the reduced insolation caused climatic cooling across the CLP. In addition, the decreasing insolation gradient between northern low and middle latitudes (Fig. 7) limited the transport of heat and moisture (Berger 1976; Young \& Bradley 1984) from low-latitude oceans to the mid-latitude CLP, thus weakening the strength of the summer monsoon circulation. Under the combined effects of these factors, the glacial climatic conditions in the CLP became colder and more arid during the early and late stages of the last two glacials, and the resulting environment favored the growth of members of the CA group (Fig. 4), especially V. tenera and P. aeoli.

In contrast, during the middle intervals of the last two glacials, relatively high obliquity resulted in increased summer insolation in northern high and middle latitudes, and in an increased summer insolation gradient between northern middle and low latitudes (Laskar et al. 2004) (Fig. 7); consequently, the strength of the winter monsoon was reduced. Conversely, the summer monsoon in low to middle latitudes was enhanced, which increased the transport of heat and moisture from the low-latitude oceans to the mid-latitude CLP. These combined effects weakened the glacial intensity and resulted in relatively mild climatic conditions during the middle stages of the last two glacials, which limited the growth of the mollusk species of the CA group, especially $V$. tenera and P. aeoli (Fig. 6).

Although external astronomical factors, as discussed above, may have imparted the tripartite structure of the last two glacials (MIS 6 and MIS 4-2), internal factors within the climate system may 
also have influenced the variations in glacial intensity. The results of simulated ice sheet changes (Abe et al. 2013) showed that the largest North American ice volume occurred in the late stages of the last two glacials, corresponding to the increased abundance of $V$. tenera and $P$. aeoli in our records (Fig. 7), both records indicating the occurrence of the coldest and most arid periods. The variations of European ice sheet volume were only about half those of the North American ice sheets (Fig. 7) during the same periods, which implies that North-American ice volume may have had a major role in the climate system and therefore a greater impact on the CLP. The second largest North American ice sheet volume occurred in the early stages of the last two glacials, in parallel with the variations of $V$. tenera and P. aeoli (Fig. 7), both records documenting an intermediate glacial intensity. In the middle parts of the glacials, a relatively low North American ice volume was associated with a lower abundance of the individuals of $V$. tenera and $P$. aeoli (Fig. 7), and thus was closely related to relatively mild climatic conditions in the CLP. Furthermore, the North American ice volume during MIS 2 was larger than that during the late stage of MIS 6 (Bintanja et al. 2005; Abe et al. 2013) (Fig. 7), which was related to a much greater glacial intensity during MIS 2 compared with MIS 6.

A second possible factor influencing the intensity of the last two glacials across the CLP may have been tropical ocean circulation. Influenced by the Southeast Asian summer monsoon, the climate of the CLP is sensitive to changes in the SST of the tropical Pacific and Indian oceans (Zhang \& Lin 1985; Liu \& Ding 1993). Increased SST generally favors an increase in warm, humid airflows to the CLP. Reconstructed SSTs for the tropical Pacific Ocean (Liu \& Herbert 2004; Herbert et al. 2010) and Indian Ocean (Herbert et al. 2010) indicate lowest SSTs during the late stages of the last two glacials, less low SSTs during the early stages, and relative high SSTs during the middle stages. In addition, marine records also indicate that the SST during MIS 2 was much lower than that during the late MIS 6 (Liu \& Herbert 2004; Herbert et al. 2010). As a result, the heat transport capacity from the tropical oceans to the CLP during MIS 2 was much weaker than during late MIS 6. Therefore, the much colder tropical oceans and a larger Arctic ice sheet may have contributed to the extremely cold and arid climatic conditions during MIS 2.

Overall, the combined influences of the variations in the Northern Hemisphere ice sheets and changes in the circulation of the tropical oceans seemingly led to the observed diverse glacial intensities in the CLP. The relatively large North American ice sheet and cooler tropical oceans may have promoted a stronger glacial climate, while the smaller North American ice sheet and warm 
tropical oceans resulted in a mild interstadial climate.

\section{Conclusions}

We have obtained terrestrial mollusk records from the L2 and L1 loess layers at two sites in the CLP, and they indicate that the last two glacials both exhibit a tripartite structure but with different glacial intensities. The first stage, from $\sim 191$ to $184 \mathrm{ka}$ for MIS 6 , and from $\sim 71-57 \mathrm{ka}$ for MIS 4 , was dominated by a cold, arid climate, as indicated by the abundance of $V$. tenera and $P$. aeoli, and the limited occurrence of thermo-humidiphilous (TH) species. The second stage, from $\sim 184$ to 155 ka for MIS 6, and from $\sim 57$ to 29 ka for MIS 3, was characterized by a relatively mild, humid climate, as reflected by decreases in $V$. tenera and $P$. aeoli, and an increase in $\mathrm{TH}$ species. During the third stage, from $\sim 155$ to $130 \mathrm{ka}$ for MIS 6, and from $\sim 29.0-11.7 \mathrm{ka}$ for MIS 2, the climatic conditions of MIS 2 were much colder and drier than those during the late MIS 6 stage, which reduced the extent of grassland environments necessary for the growth of both $\mathrm{CA}$ and $\mathrm{TH}$ species such that their abundances were rare $(<50 / 15 \mathrm{~kg})$.

We consider that the tripartite structure was mainly imparted by variations in obliquity. The cold, arid climatic conditions during the early and late glacial stages may have been influenced by lower obliquity that reduced the summer insolation at high latitudes and weakened the summer insolation gradient between middle and low latitudes. The relatively mild, humid climate during the middle stage of the glacials was primarily driven by a higher obliquity that reduced the Northern Hemisphere ice volume and enhanced the transport of heat and moisture from low-latitude oceans to the mid-latitude CLP. Hence, we suggest that glacial intensity was impacted by both external and internal factors. Besides the external effects of obliquity, variations in Northern Hemisphere ice sheets and the circulation of the tropical oceans may have played important roles in driving the observed variations in glacial intensity at different times. Relatively small ice sheets and warm tropical oceans would have promoted the mild, humid interstadial conditions during the middle stages of MIS 6 and MIS 3 in the CLP. Relatively large ice sheets and cooler tropical oceans, on the other hand, may have strengthened the cold, arid climate during the early and late stages of both glacials. Different from the cold, dry climate during late MIS 6, MIS 2 was characterized by the coldest and most arid climate in the CLP during the last two glacials, which may have been caused by a much larger North American ice sheet 
and lower tropical SSTs. We note that further modelling simulations are needed to substantiate this hypothesis.

Acknowledgements. - We thank Drs. Luo Wang, Qingzhen Hao, Xinxin Zuo, Xiaoyan Yang and Kai Niu for constructive suggestions. Denis Didier Rousseau acknowledges Prof. Tungsheng Liu for inviting him to collaborate with Chinese colleagues in the study of loess mollusks from the CLP. We would like to thank Jan Bloemendal for English language editing. We are grateful to the two reviewers for their useful suggestions and to Prof. Jan A. Piotrowski for his help in the correction of this paper. This study was supported by the Strategic Priority Research Program of the Chinese Academy of Sciences (grant No. XDB26000000) and the National Natural Science Foundation of China (grant Nos. 41430103, 41888101 and 41772186).

Author contributions. - NW, DZ, and HL conceived and designed the study. NW, FL, XC, DDR, and YD undertook the field work. NW, XC, YD, and DDR collected and counted snail individuals. DZ, FL, and DDR established the chronology of the studied sections. DZ, NW, FL, HL, DDR, XC, and YD wrote the manuscript. DZ, NW, HL, FL, and DDR contributed to the interpretation of the results and all the authors provided inputs to the final manuscript.

\section{References}

Abe, O. A., Saito, F., Kawamura, K., Raymo, M. E., Okuno, J. I., Takahashi, K. \& Blatter, H. 2013: Insolation-driven 100,000-year glacial cycles and hysteresis of ice-sheet volume. Nature 500, 190-194.

An, Z. S., Kukla, G., Porter, S. C. \& Xiao, J. L. 1991a: Magnetic susceptibility evidence of monsoon variation on the Loess Plateau of central China during the last 130,000 years. Quaternary Research 36, 29-36.

An, Z. S., Kukla, G., Porter, S. C. \& Xiao, J. L. 1991b: Late Quaternary dust flow on the Chinese loess plateau. Catena 18, 125-132.

Berger, A. 1976: Long-term variation of daily and monthly insolation during last Ice Age. Eos, Transactions American Geophysical Union 57, 254-254.

Bintanja, R., Van, D. W., Roderik, S. W. \& Oerlemans, J. 2005: Modelled atmospheric temperatures and global sea levels over the past million years. Nature 437, 125-128.

Bühring, C., Sarnthein, M. \& Erlenkeuser, H. 2004: Toward a high-resolution stable isotope stratigraphy of the last 1.1 m.y.: Site 1144, South China Sea. In: Prell, W. L., Wang, P., Blum, P., Rea, D. K., Clemens, S. C. (eds.): Proceedings of the Ocean Drilling Program. Scientific Results 184, 1-29.

Chen, D. N. \& Gao, J. X. 1987: Economic Fauna Sinica of China, Terrestrial Mollusca. 186 pp. 

Science Press, Beijing (in Chinese).

Cheng, H., Edwards, R. L., Sinha, A., Spötl, C., Yi, L., Chen, S. T., Kelly, M., Kathayat, G., Wang, X. F., Li, X. L., Kong, X. G., Wang, Y. J., Ning, Y. F. \& Zhang, H. W. 2016: The Asian monsoon over the past 640,000 years and ice age terminations. Nature 534, 640-646.

Dansgaard, W., Johnsen, S. J., Clausen, H. B., Dahljensen, D., Gundestrup, N. S., Hammer, C. U., Hvidberg, C. S., Steffensen, J. P., Sveinbjornsdottir, A. E., Jouzel, J. \& Bond, G. 1993: Evidence for General Instability of Past Climate from a 250-Kyr Ice-Core Record. Nature 364, 218-220.

Ding, Z. L., Liu, T. S., Rutter, N. W., Yu, Z. W., Guo, Z. T. \& Zhu, R. X. 1995: Ice-volume forcing of East Asian winter monsoon variations in the past 800,000 years. Quaternary Research 44, 149-159.

Ding, Z. L., Ren, J. Z., Yang, S. L. \& Liu, T. S. 1999: Climate instability during the penultimate glaciation: Evidence from two high-resolution loess records, China. Journal of Geophysical Research: Solid Earth 104, 20123-20132.

Ding, Z. L., Derbyshire, E., Yang, S. L., Yu, Z. W., Xiong, S. F. \& Liu, T. S. 2002: Stacked 2.6-Ma grain size record from the Chinese loess based on five sections and correlation with the deep-sea $\delta^{18} \mathrm{O}$ record. Paleoceanography 17, doi 10.1029/2001PA000725.

Dong, Y. J., Wu, N. Q., Li, F. J., Chen, X. Y., Zhang, D., Zhang, Y. T., Huang, L. P., Wu, B. \& Lu, H. Y. 2019: Influence of monsoonal water-energy dynamics on terrestrial mollusk species-diversity gradients in northern China. Science of The Total Environment 676, 206-214.

Grant, K. M., Rohling, E. J., Ramsey, C. B., Cheng, H., Edwards, R. L., Florindo, F., Heslop, D., Marra, F., Roberts, A. P., Tamisiea, M. E. \& Williams, F. 2014: Sea-level variability over five glacial cycles. Nature Communications 5, doi 10.1038/ncomms6076.

Guo, Z. T., Liu, T. S., Fedoroff, N., Wei, L. Y., Ding, Z. L., Wu, N. Q., Lu, H. Y., Jiang, W. Y. \& An, Z. S. 1998: Climate extremes in loess of China coupled with the strength of deep-water formation in the North Atlantic. Global and Planetary Change 18, 113-128.

Hao, Q. Z., Wang, L., Oldfield, F., Peng, S. Z., Qin, L., Song, Y., Xu, B., Qiao, Y. S., Bloemendal, J. \& Guo, Z. T. 2012: Delayed build-up of Arctic ice sheets during 400,000-year minima in insolation variability. Nature 490, 393-396.

Hao, Q. Z., Wang, L., Oldfield, F. \& Guo, Z. T. 2015: Extra-long interglacial in Northern Hemisphere during MISs 15-13 arising from limited extent of Arctic ice sheets in glacial MIS 14. Scientific reports 5, doi 10.1038/srep12103.

Han, J. M., Keppens, E., Liu, T. S., Paepe, R. \& Jiang, W. Y. 1997: Stable isotope composition of the carbonate concretion in loess and climate change. Quaternary International 37, 37-43.

Hays, J. D., Imbrie, J. \& Shackleton, N. J. 1976: Variations in earths orbit-pacemaker of ice ages. Science 194, 1121-1132.

Herbert, T. D., Peterson, L. C., Lawrence, K. T. \& Liu, Z. H. 2010: Tropical ocean temperatures over the past 3.5 million years. Science $328,1530-1534$.

Horsák, M., Chytrý, M. \& Axmanová, I. 2013: Exceptionally poor land snail fauna of central Yakutia (NE Russia): climatic and habitat determinants of species richness. Polar Biology 36, 185-191.

Jiang, W. Y., Yang, X. X. \& Cheng, Y. F. 2014: Spatial patterns of vegetation and climate on the Chinese Loess Plateau since the Last Glacial Maximum. Quaternary international 334, 52-60.

Kukla, G. 1987: Loess stratigraphy in central China. Quaternary Science Reviews 6, 191-219.

Kukla, G. \& An, Z. 1989: Loess stratigraphy in central China. Palaeogeography, Palaeoclimatology, Palaeoecology 72, 203-225. 
Lang, N. \& Wolff, E. W. 2011: Interglacial and glacial variability from the last 800 ka in marine, ice and terrestrial archives. Climate of the Past 7, 361-380.

Laskar, J., Robutel, P., Joutel, F., Gastineau, M., Correia, A. C. M. \& Levrard, B. 2004: A long-term numerical solution for the insolation quantities of the Earth. Astronomy \& Astrophysics 428, 261-285.

Lawrence, K. T., Herbert, T. D., Brown, C. M., Raymo, M. E. \& Haywood, A. M. 2009: High-amplitude variations in North Atlantic sea surface temperature during the early Pliocene warm period. Paleoceanography 24, doi 10.1029/2008PA001669.

Li, F. J., Wu, N. Q., Pei, Y. P., Hao, Q. Z. \& Rousseau, D. D. 2006: Wind-blown origin of Dongwan late Miocene-Pliocene dust sequence documented by land snail record in western Chinese Loess Plateau. Geology 34, 405-408.

Li, F. J., Rousseau, D. D., Wu, N. Q., Hao, Q, Z. \& Pei, Y. P. 2008: Late Neogene evolution of the East Asian monsoon revealed by terrestrial mollusk record in Western Chinese Loess Plateau: from winter to summer dominated sub-regime. Earth and Planetary Science Letters 274, 439-447.

Li, F. J. \& Wu, N. Q. 2010: Pliocene land snail record from western Chinese Loess Plateau and implications for impacts of the summer insolation gradient between middle and low latitudes on the East Asian summer monsoon. Global and Planetary Change 72, 73-78.

Lisiecki, L. E. \& Raymo, M. E. 2005: A Pliocene-Pleistocene stack of 57 globally distributed benthic $\delta^{18} \mathrm{O}$ records. Paleoceanography 20, doi 10.1029/2004PA001071.

Liu, T. S. 1985: Loess and the Environment. 251 pp. China Ocean Press, Beijing (in Chinese).

Liu, T. S. \& Ding, Z. L. 1993: Stepwise coupling of monsoon circulations to global ice volume variations during the late Cenozoic. Global and Planetary Change 7, 119-130.

Liu, Z. H. \& Herbert, T. D. 2004: High-latitude influence on the eastern equatorial Pacific climate in the early Pleisocene epoch. Nature 427, 720-723.

Ložek, V. 1964: Quartärmollusken der Tschechoslowakei. Rozpravy Ústředního ústavu geologického 31, 1-374.

Ložek, V. 1990: Molluscs in loess, their paleoecological significance and role in geochronology_Principles and methods. Quaternary International 77, 1-79.

Milankovitch, M. 1941: Kanon der Erdebestrahlung und seine Anwendung auf das Eiszeitenproblem. 484 pp. Stamparija Mihaila Ćurčića, Beograd. (Translated version, 1998: Canon of Insolation and the Ice-age Problem. Zavod za udžbenike i nastavna sredstva)

Nekola, J. C., Coles, B. F. \& Horsak, M. 2015: Species assignment in Pupilla (Gastropoda: Pulmonata: Pupillidae): integration of DNA-sequence data and conchology. Journal of Molluscan Studies 81, 196-216.

Petit, J. R., Jouzel, J., Raynaud, D., Barkov, N. I., Barnola, J. M., Basile, I., Bender, M., Chappellaz, J., Davis, M., Delaygue, G., Delmotte, M., Kotlyakov, V. M., Legrand, M., Lipenkov, V. Y., Lorius, C., Pepin, L., Ritz, C., Saltzman, E. \& Stievenard, M. 1999: Climate and atmospheric history of the past 420,000 years from the Vostok ice core, Antarctica. Nature 399, 429-436.

Porter, S. C. \& An, Z. S. 1995: Correlation between climate events in the North Atlantic and China during the last glaciation. Nature 375, 305-308.

Puisségur, J. J. 1976: Mollusques continentaux quaternaries de Bourgogne: significations stratigraphiques et climatiqus. Rapports avecd'autres faunes boréales de France. 241pp. Centre de Palégégraphie et de Palébiologie Evolutives, Universitéde Dijon.

Raymo, M. E., Oppo, D. W., Flower, B. P., Hodell, D. A., Mcmanus, J. F., Venz, K. A., Kleiven, K. F. 
\& Mcintyre, K. 2004: Stability of North Atlantic water masses in face of pronounced climate variability during the Pleistocene. Paleoceanography 19, doi 10.1029/2003PA000921.

Rossignol, J., Moine, O. \& Rousseau, D. D. 2004: The Buzzard's Roost and Eustis mollusc sequences: comparison between the paleoenvironments of two sites in the Wisconsinan loess of Nebraska, USA. Boreas 33, 145-154.

Rousseau, D. D. 1985: Structures des populations quaternaires de pupilla muscorum (gastropode) en Europe du Nord: relations avec leurs environnements. Geobios 18, 407.

Rousseau, D. D. 1987: Paleoclimatology of the Achenheim series (middle and upper pleistocene, Alsace, France). A malacological analysis. Palaeogeography, Palaeoclimatology, Palaeoecology 59, 293-314.

Rousseau, D. D. \& Puisségur, J. J. 1990: A 350,000-year climatic record from the loess sequence of Achenheim, Alsace, France. Boreas 19, 203-216.

Rousseau, D. D. 1991: Climatic transfer function from Quaternary molluscs in European loess deposits. Quaternary Research 36, 195-209.

Rousseau, D. D. \& Kukla, G. 1994: Late Pleistocene climate record in the Eustis loess section, Nebraska, based on land snail assemblages and magnetic susceptibility. Quaternary Research 42, 176-187.

Rousseau, D. D. \& Wu, N. Q. 1997: A new molluscan record of the monsoon variability over the past $130000 \mathrm{yr}$ in the Luochuan loess sequence, China. Geology 25, 275-278.

Rousseau, D. D. \& Wu, N. Q. 1999: Mollusk record of monsoon variability during the L2-S2 cycle in the Luochuan loess sequence, China. Quaternary Research 52, 286-292.

Shackleton, N. J., Backman, J., Zimmerman, H. T., Kent, D. V., Hall, M. A., Roberts, D. G., Schnitker, D., Baldauf, J. G., Desprairies, A. \& Homrighausen, R. 1984: Oxygen isotope calibration of the onset of ice-rafting and history of glaciation in the North Atlantic region. Nature 307, 620-623.

Spratt, R. M. \& Lisiecki, L. E. 2016: A Late Pleistocene sea level stack. Climate of the Past Discussions 11, 3699-3728.

Sun, X. J., Luo, Y. L., Huang, F., Tian, J. \& Wang, P. X. 2003: Deep-sea pollen from the South China Sea: Pleistocene indicators of East Asian monsoon. Marine Geology 201, 97-118.

Tzedakis, P. C., Hooghiemstra, H. \& Pälike, H. 2006: The last 1.35 million years at Tenaghi Philippon: revised chronostratigraphy and long-term vegetation trends. Quaternary Science Reviews 25, 3416-3430.

Wu, B. \& Wu, N. Q. 2011: Terrestrial mollusc records from Xifeng and Luochuan L9 loess strata and their implications for paleoclimatic evolution in the Chinese Loess Plateau during marine Oxygen Isotope Stages 24-22. Climate of the Past 7, 349-359.

Wu, N. Q., Rousseau, D. D. \& Liu, D. S. 1996: Land mollusk records from the Luochuan loess sequence and their paleoenvironmental significance. Science in China: Series D Earth Sciences 39, 494-502.

Wu, N. Q., Lu, H. Y. \& Guo, Z. T. 1997: Reconstruction of paleoclimate in the Loess Plateau using non-linear mathematical methods. Chinese Science Bulletin 42: 1014-1016.

Wu, N. Q., Rousseau, D. D. \& Liu, D. S. 1999: Climatic instability recorded by the mollusk assemblages from the late glacial loess deposits in China. Chinese science bulletin 44, 1238-1242.

Wu, N. Q., Rousseau, D. D. \& Liu, X. P. 2000: Response of mollusk assemblages from the Luochuan loess section to orbital forcing since the last $250 \mathrm{ka}$. Chinese Science Bulletin 45, 1617-1622.

Wu, N. Q., Rousseau, D. D., Liu, T. S., Lu, H. Y., Gu, Z. Y., Guo, Z. T. \& Jiang, W. Y. 2001: Orbital 
forcing of terrestrial mollusks and climatic changes from the Loess Plateau of China during the past 350 ka. Journal of Geophysical Research: Atmospheres 106, 20045-20054.

Wu, N. Q., Liu, T. S., Liu, X. P. \& Gu, Z. Y. 2002: Mollusk record of millennial climate variability in the Loess Plateau during the Last Glacial Maximum. Boreas 31, 20-27.

Wu, N. Q., Pei, Y. P., Lu, H. Y., Guo, Z. T., Li. F. J. \& Liu, T. S. 2006: Marked ecological shifts during 6.2-2.4 Ma revealed by a terrestrial molluscan record from the Chinese Red Clay Formation and implication for palaeoclimatic evolution. Palaeogeography, Palaeoclimatology, Palaeoecology 233, 287-299.

Wu, N. Q., Chen, X. Y., Rousseau, D. D., Li, F. J., Pei, Y. P. \& Wu, B. 2007: Climatic conditions recorded by terrestrial mollusc assemblages in the Chinese Loess Plateau during marine Oxygen Isotope Stages 12-10. Quaternary Science Reviews 26, 1884-1896.

Wu, N. Q., Li, F. J. \& Rousseau, D. D. 2018: Terrestrial mollusk records from Chinese loess sequences and changes in the East Asian monsoonal environment. Journal of Asian Earth Sciences 155, $35-48$.

Yen, T. C. 1939: Die Chinesischen Land- und Süßwasser-Gastropoden des Natur-Museums Senckenberg. Abhandlungen der Senckenbergischen Naturforschenden Gesellschaft 444, 1-235.

Young, M. A. \& Bradley, R. S. 1984: Insolation gradients and the paleoclimatic record. In: Berger Imbrie, J., Hays, J., Kukla, G. \& Saltzman B. (eds.): Milankovitch and Climate. NATO ASI Series (Series C: Mathematical and Physical Sciences) 126, 707-713. Springer, Dordrecht.

Zhang, J. C. \& Lin, Z. G. 1985: Climate of China. 607 pp. Shanghai Scientific and Technical Publishers, Shanghai (in Chinese).

Zhou, B., Wali, G., Peterse, F. \& Bird, M. I. 2016: Organic carbon isotope and molecular fossil records of vegetation evolution in central Loess Plateau since $450 \mathrm{kyr}$. Science China Earth Sciences 59, 1206-1215. 
Figure 1. Location of the study sites in the CLP. A. Inset map shows the location of the CLP and the pathways of the East Asian winter monsoon (EAWM) (blue arrows) and summer monsoon (EASM) (red arrows); B. Map of the CLP showing the locations of the Xifeng and Luochuan sections (blue triangles).

Figure 2. Comparison of the variations in magnetic susceptibility (MS, grey lines) and the abundance of Vallonia tenera and Pupilla aeoli (VP, purple lines) from the Xifeng and Luochuan sections (this study), a previously published magnetic susceptibility record (red lines) (Hao et al. 2012), and the LR04 marine oxygen isotope stack (blue line). $\mathrm{S}=$ palaeosol; $\mathrm{L}=$ loess; LR04 is benthic $\delta^{18} \mathrm{O}$ stack of 57 global records compiled by Lisiecki \& Raymo (2005). 1-7 = Marine Isotope Stages 1-7.

Figure 3. Typical mollusk species identified in the L2 and L1 units of the Xifeng and Luochuan sections. 1 and $2=$ Pupilla aeoli; 3 and $4=$ Pupilla cf. muscorum; $5-7=$ Vallonia tenera $; 8-10=$ Punctum orphana $; 11-13=$ Cathaica pulveratrix $; 14-16=$ Cathaica sp. The scale bars represent $1 \mathrm{~mm}$.

Figure 4. Variations in the counts of whole mollusks in the upper two loess units (L2 and L1) of the Xifeng section (A), and the Luochuan section (B) (number of individuals counted per $15 \mathrm{~kg}$ ). Cold-aridiphilous (CA, dark blue solid shading), cool-humidiphilous ( $\mathrm{CH}$, light blue shading), thermo-humidiphilous (TH, red shading) species; total mollusk individuals (black shading), sum of the number of mollusk species (blue line), and the results of a cluster analysis of the assemblages. The light blue background represents cold, dry glacial periods, and the light orange background represents mild, humid interstadial periods. $\mathrm{S}=$ palaeosol; $\mathrm{L}=$ loess; $\mathrm{MS}=$ magnetic susceptibility; CONISS $=$ constrained incremental sum of squares; MIS = Marine Isotopic Stage.

Figure 5. Results of hierarchical cluster analysis of all of the mollusk species within the interval of L2-S0 ( $\mathrm{L}=$ loess; $\mathrm{S}=$ palaeosol) at Xifeng (A) and Luochuan (B). The $\mathrm{Y}$ axis represents the distance between the identified species and the cluster center.

Figure 6. Variations in the total of $V$. tenera and P. aeoli (VP) in the upper two loess units (L2 and L1) of the Xifeng and Luochuan sections. Magnetic susceptibility (MS, orange lines), VP individuals (purple lines, on a reversed scale), VP percentages (black lines, on a reversed scale), and the LR04 marine $\delta^{18} \mathrm{O}$ stack (blue line, on a reversed scale). The Luochuan data are from Wu et al. (1996, 1999, 2000) and Rousseau \& Wu (1997, 1999). The light blue background represents cold, dry glacial periods, and the light orange background represents mild, humid interstadial periods. The red stippled area indicates period in which snail fossils were rare $(<50 / 15 \mathrm{~kg})$. LR04 is a benthic $\delta^{18} \mathrm{O}$ stack of 57 global records compiled by Lisiecki \& Raymo (2005). MIS = Marine Isotopic Stage.

Figure 7. Comparison of profiles of the counts of $V$. tenera and P. aeoli (VP, purple lines) in loess units L2 and L1 of the Xifeng and Luochuan sequences with records of North American and European ice volume (equivalent to sea level) (Bintanja et al. 2005), the LR04 benthic $\delta^{18} \mathrm{O}$ stack (Lisiecki \& Raymo 2005), and Earth orbital parameters (obliquity, precession, $65^{\circ} \mathrm{N}$ insolation and the mean summer insolation gradient between $35^{\circ} \mathrm{N}$ and $0^{\circ}$ ) (Laskar et al. 2004). The light blue background represents cold, dry glacial periods, and the light orange background represents mild, humid interstadial periods. 
597 The red stippled areas are intervals in which snail fossils were rare $(<50 / 15 \mathrm{~kg})$. LR04 is a benthic $598 \delta^{18} \mathrm{O}$ stack comprising 57 global records compiled by Lisiecki \& Raymo (2005). MIS = Marine 599 Isotopic Stage. Note that several X axes are reversed so that the warming occurs in a consistent 600 direction (i.e. to the right).

601 Table 1. Selected age-control points for the Xifeng and Luochuan profiles, used to establish a 602 chronology via comparison with a grain-size age model of Hao et al. (2012).

603 Table 2. List of mollusk species identified in loess units L2 and L1 of the Xifeng and Luochuan 604 sections

605 
2

4

5

6

7

8

11

12

13

14

15

16

17

18

19

20

21

22

23

24

25

26

27

28

29

30

31

32

33

34

35

36

37

38

39

40

41

42

43

44

45

46

47

48

49

50

51

52

53

54

55

56

57

58

59

60

606 Supporting information

607 Table S1. Dataset of the number of Vallonia tenera and Pupilla aeoli (VP) individuals in loess units L2 608 and L1 of the Xifeng section.

609 Table S2. Dataset of the number of Vallonia tenera and Pupilla aeoli (VP) individuals in loess units L2 610 and L1 from the Luochuan section. 


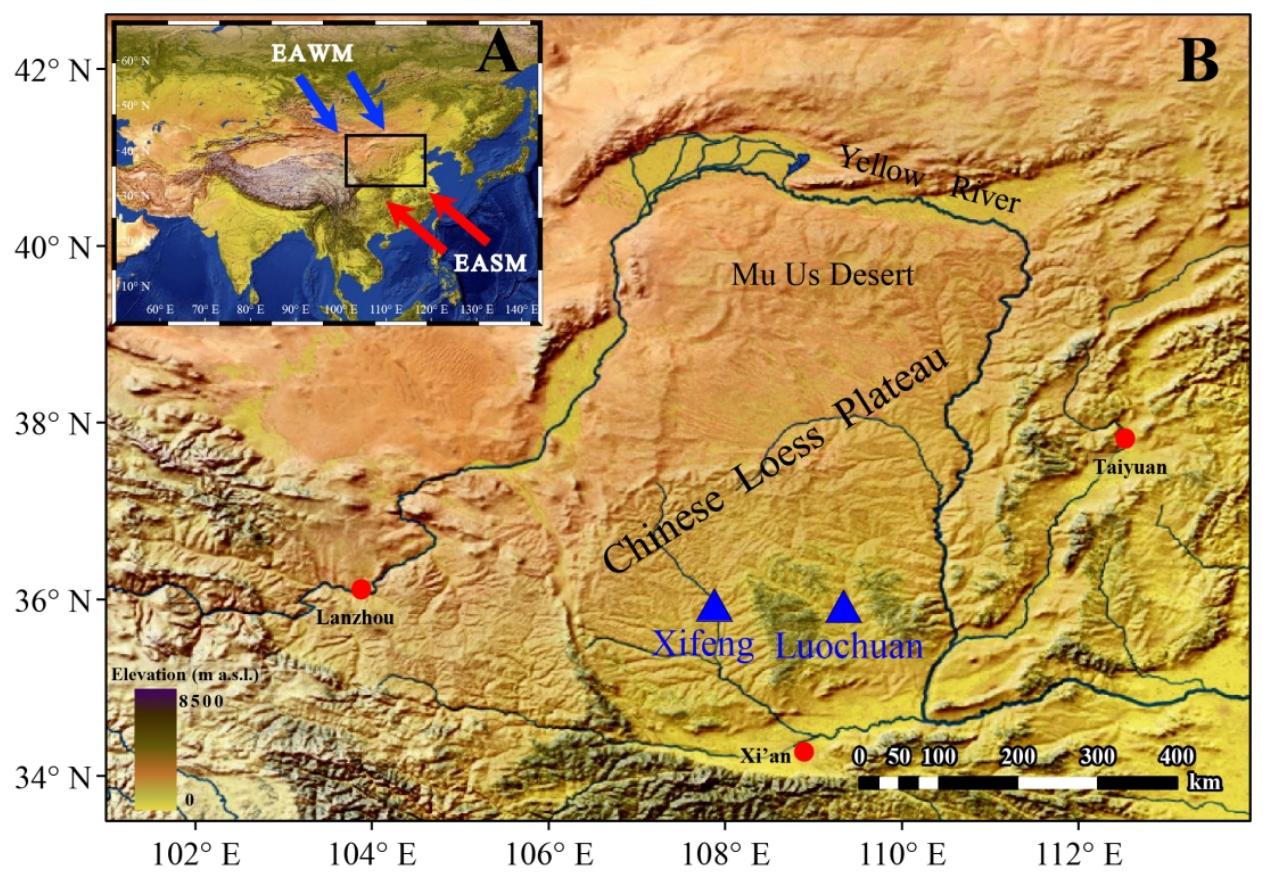

$196 \times 136 \mathrm{~mm}(300 \times 300 \mathrm{DPI})$ 


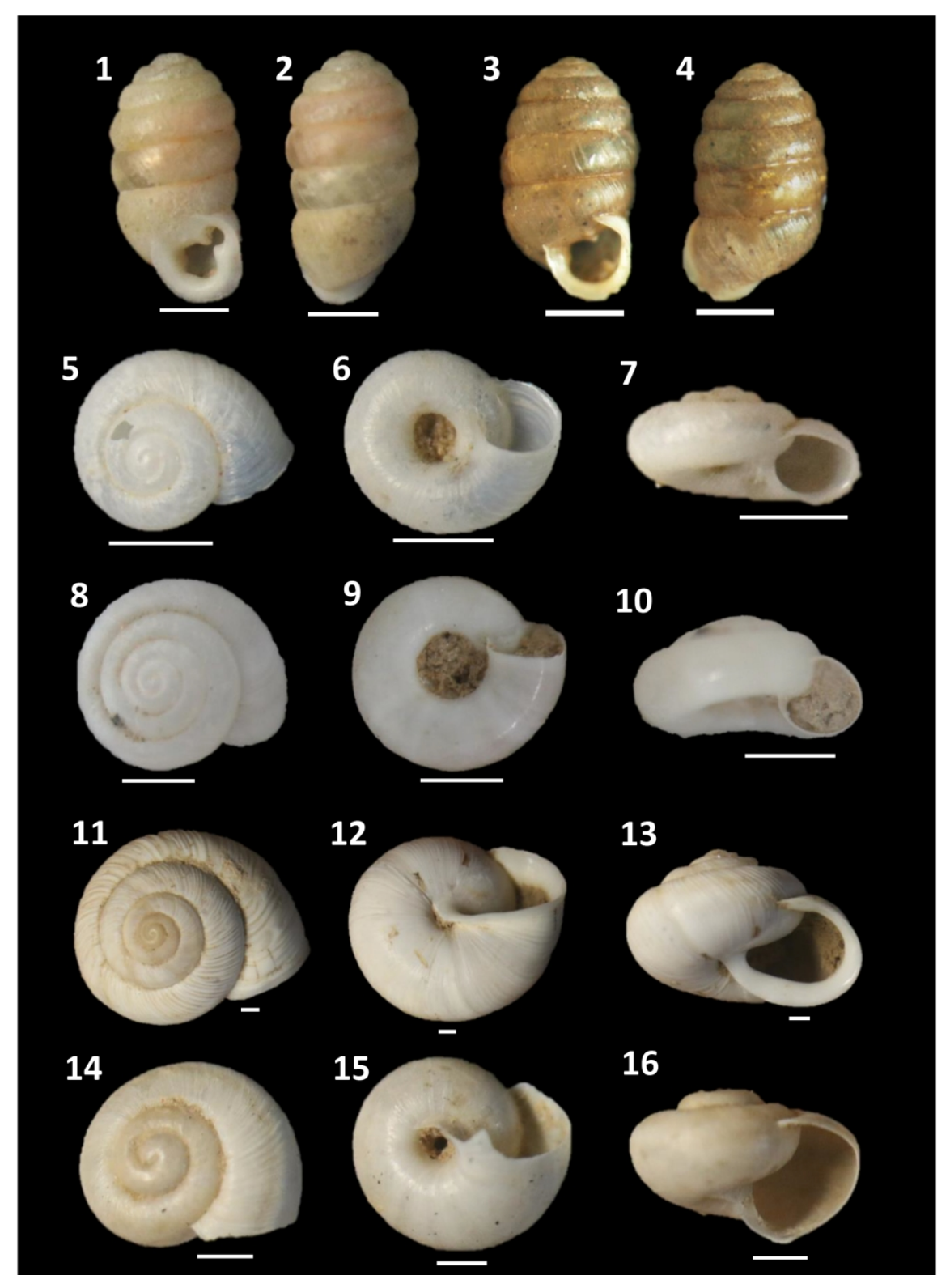

$176 \times 235 \mathrm{~mm}(300 \times 300 \mathrm{DPI})$ 


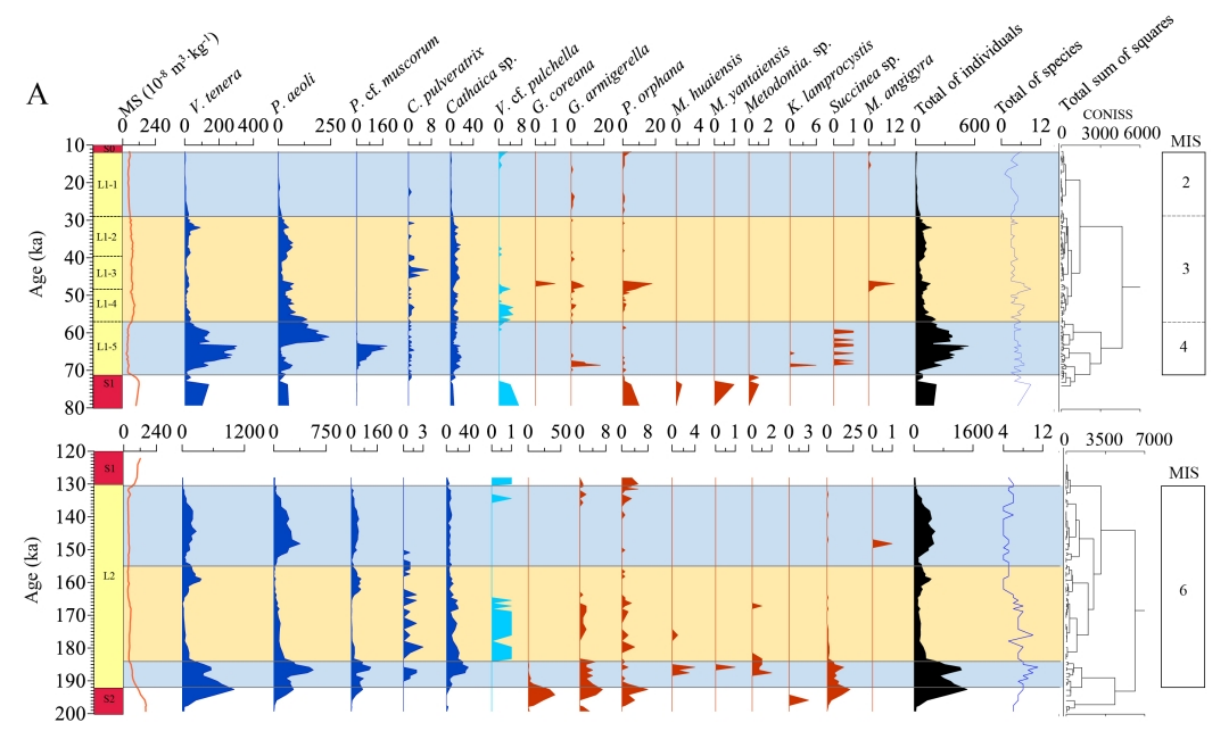

B
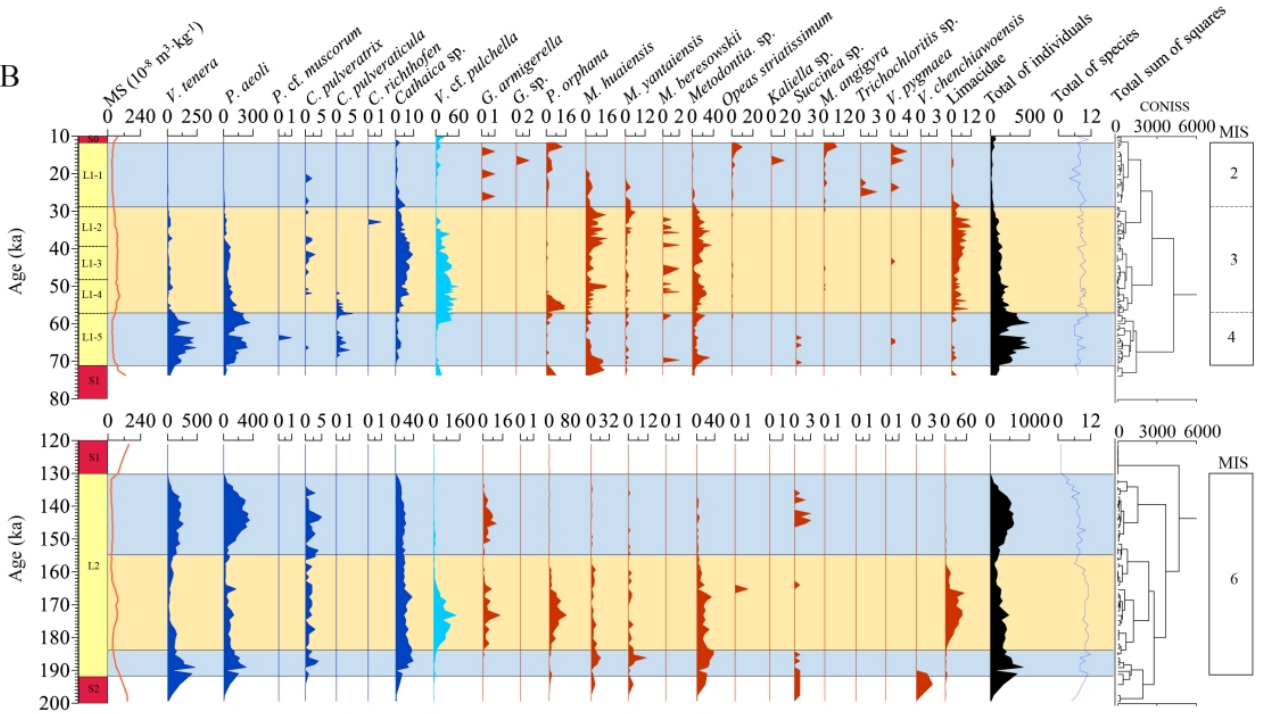

$259 \times 295 \mathrm{~mm}(300 \times 300$ DPI $)$ 
10 11 12 13 14 15 16 17 18 19 20 21 22 23

24 25 26 27 28 29 30 31 32 33 34 35 36 37 38 39 40 41 42 43 44 45 46 47 48 49 50 51 52 53 54 55 56 57 58 59 60
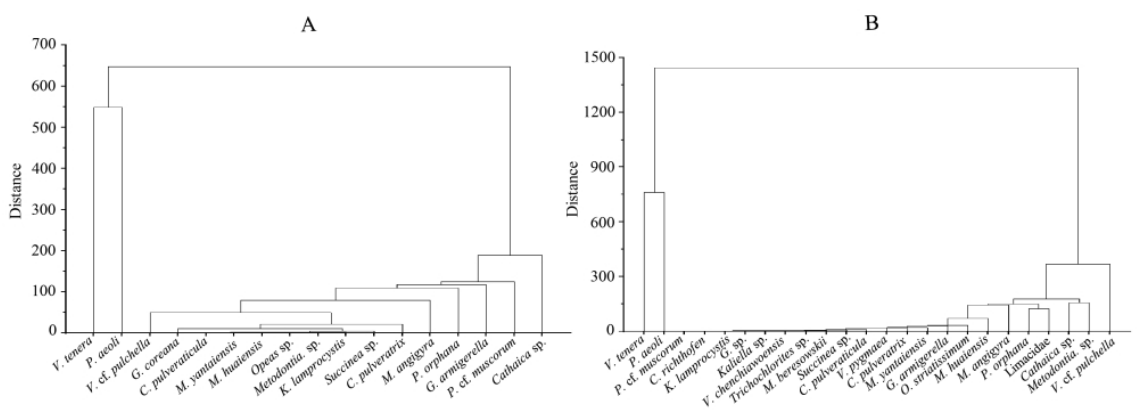

$338 \times 190 \mathrm{~mm}(300 \times 300 \mathrm{DPI})$ 

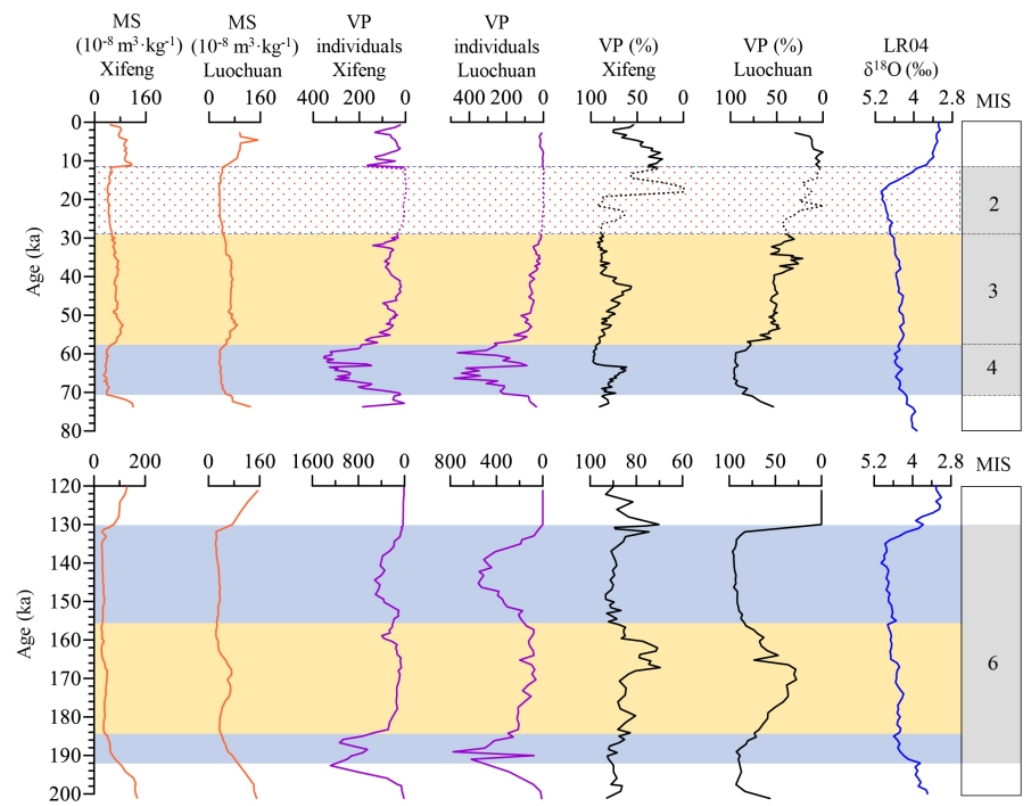

$254 \times 190 \mathrm{~mm}(300 \times 300 \mathrm{DPI})$ 


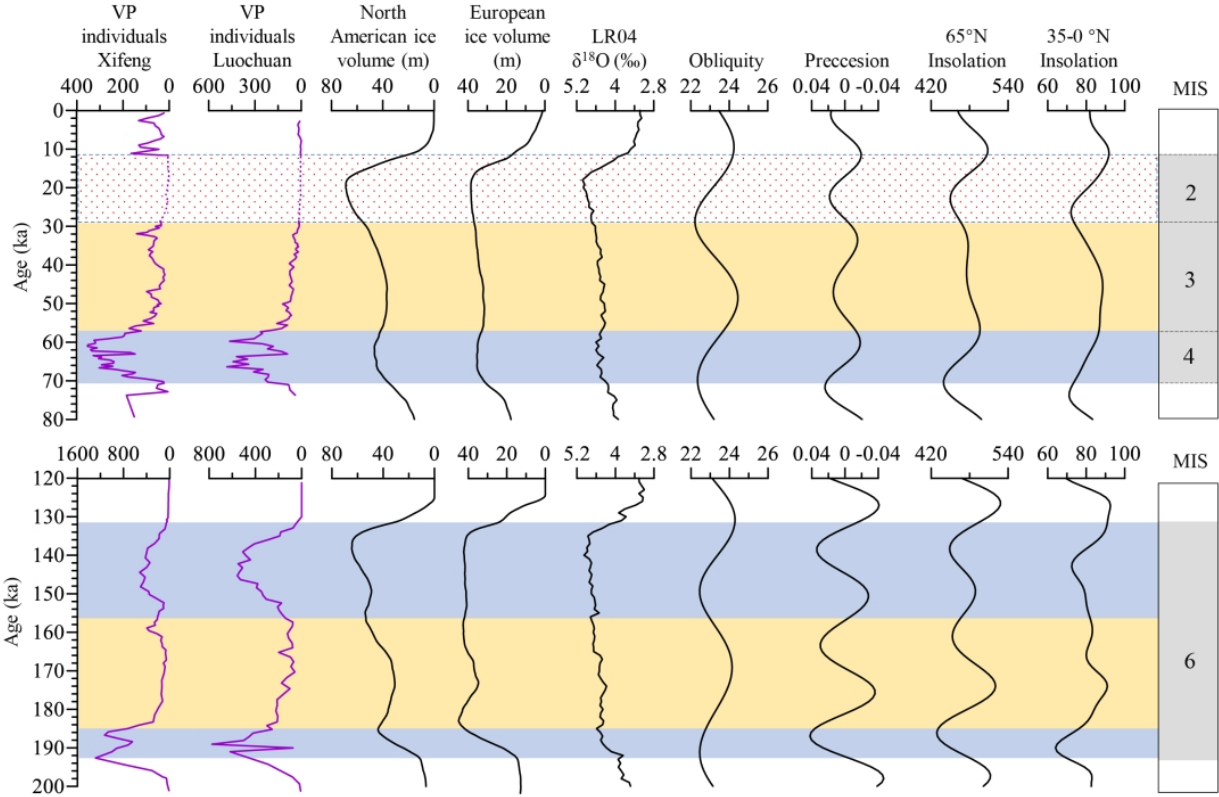

$254 \times 190 \mathrm{~mm}(300 \times 300$ DPI $)$ 
Table 1. Selected age-control points for the Xifeng and Luochuan profiles, used to establish a chronology via comparison with a grain-size age model of Hao et al. (2012).

\begin{tabular}{|c|c|c|c|}
\hline Xifeng depth (m) & Luochuan depth (m) & Age (ka) & Unit \\
\hline 0.0 & 0.0 & 0.0 & S0 top \\
\hline 0.7 & 0.6 & 4.6 & S0 \\
\hline 2.0 & 1.5 & 11.7 & S0 bottom \\
\hline 3.5 & 3.0 & 29.7 & L1 \\
\hline 4.7 & 3.7 & 34.2 & L1 \\
\hline 4.9 & 4.2 & 36.1 & L1 \\
\hline 5.6 & 4.8 & 39.6 & L1 \\
\hline 6.9 & 5.8 & 49.1 & L1 \\
\hline 8.0 & 6.8 & 52.6 & L1 \\
\hline 8.8 & 8.0 & 57.7 & L1 \\
\hline 9.1 & 8.1 & 59.1 & L1 \\
\hline 12.1 & 9.9 & 71.0 & L1/S1 boundary \\
\hline 12.4 & 10.1 & 73.8 & S1 \\
\hline 12.6 & 10.2 & 85.0 & S1 \\
\hline 13.3 & 10.4 & 96.6 & S1 \\
\hline 13.5 & 10.6 & 101.3 & S1 \\
\hline 14.0 & 11.2 & 112.4 & S1 \\
\hline 14.9 & 11.8 & 130.0 & S1/L2 boundary \\
\hline 15.4 & 11.9 & 131.9 & $\mathrm{~L} 2$ \\
\hline 16.8 & 13.6 & 149.4 & L2 \\
\hline 18.3 & 14.7 & 160.4 & L2 \\
\hline 19.3 & 15.4 & 168.9 & L2 \\
\hline 20.1 & 16.4 & 183.3 & $\mathrm{~L} 2$ \\
\hline 21.0 & 17.2 & 191.0 & L2/S2 boundary \\
\hline 21.4 & 17.4 & 197.6 & S2 \\
\hline
\end{tabular}


Table 2. List of mollusk species identified in loess units L2 and L1 of the Xifeng and Luochuan sections

\begin{tabular}{|c|c|c|}
\hline Family & Genus & Species \\
\hline Valloniidae & Vallonia & $\begin{array}{l}\text { Vallonia tenera (Reinhardt, 1877) } \\
\text { Vallonia } \text { cf. pulchella (Muller, 1774) }\end{array}$ \\
\hline Pupillidae & Gastrocopta & $\begin{array}{l}\text { Pupilla aeoli (Hilber, 1883) } \\
\text { Pupilla } \text { cf. muscorum (Linne, 1758) } \\
\text { Gastrocopta armigerella (Reinhardt, 1877) } \\
\text { Gastrocopta coreana Pilsbry, } 1916 \\
\text { Gastrocopta } \mathrm{sp} .\end{array}$ \\
\hline Endodontidae & Punctum & Punctum orphana (Heude, 1882) \\
\hline Vertiginidae & Vertigo & Vertigo chenchiawoensis Li, 1966 \\
\hline Succineidae & Succinea & Succinea sp. \\
\hline Ariophantidae & Macrochlamys & $\begin{array}{l}\text { Macrochlamys angigyra Yen, } 1939 \\
\text { Kaliella lamprocystis Moellendorff, } 1899 \\
\text { Kaliella } \mathrm{sp} .\end{array}$ \\
\hline Bradybaenidae & Cathaica & $\begin{array}{l}\text { Cathaica pulveratrix (Martens, 1882) } \\
\text { Cathaica pulveraticula (Martens, 1882) } \\
\text { Cathaica richthofen (Martens, 1873) } \\
\text { Cathaica sp. } \\
\text { Metodontia yantaiensis (Crosse and Debeaux, 1863) } \\
\text { Metodontia huaiensis (Crosse, 1882) } \\
\text { Metodontia beresowskii (Moellendorff, 1899) } \\
\text { Metodontia } \text { sp. }\end{array}$ \\
\hline Subulinidae & Opeas & Opeas striatissimum (Gredler, 1882) \\
\hline Camaenidae & Trichochloritis & Trichochloritis sp. \\
\hline Pristilomatidae & Vitrea & Vitrea pygmaea (Boettger, 1880) \\
\hline Limacidae & & \\
\hline
\end{tabular}


Table S1. Dataset of the number of Vallonia tenera and Pupilla aeoli (VP) individuals in loess units L2 and L1 from the Xifeng section.

\begin{tabular}{|c|c|c|c|c|c|c|}
\hline Depth (m) & Age (ka) & Lithology & $\begin{array}{c}\text { Magnetic } \\
\text { susceptibility }\end{array}$ & $\begin{array}{c}\text { Vallonia } \\
\text { tenera }\end{array}$ & $\begin{array}{c}\text { Pupilla } \\
\text { aeoli }\end{array}$ & VP \\
\hline 2 & 11.7 & L1 & 49.49 & 2 & 2 & 4 \\
\hline 2.1 & 12.9 & L1 & 54.76 & 4 & 0 & 4 \\
\hline 2.2 & 14.1 & L1 & 44.78 & 4 & 0 & 4 \\
\hline 2.3 & 15.3 & L1 & 47.96 & 1 & 0 & 1 \\
\hline 2.4 & 16.5 & L1 & 41.58 & 0 & 0 & 0 \\
\hline 2.5 & 17.7 & L1 & 39.60 & 0 & 0 & 0 \\
\hline 2.6 & 18.9 & L1 & 43.78 & 3 & 2 & 5 \\
\hline 2.7 & 20.1 & L1 & 39.70 & 3 & 4 & 7 \\
\hline 2.8 & 21.3 & L1 & 44.55 & 6 & 8 & 14 \\
\hline 2.9 & 22.5 & L1 & 44.06 & 5 & 2 & 7 \\
\hline 3 & 23.7 & L1 & 43.75 & 5 & 3 & 8 \\
\hline 3.1 & 24.9 & L1 & 46.27 & 5 & 5 & 10 \\
\hline 3.2 & 26.1 & L1 & 46.77 & 12 & 5 & 17 \\
\hline 3.3 & 27.3 & L1 & 49.25 & 16 & 10 & 26 \\
\hline 3.4 & 28.5 & L1 & 53.66 & 23 & 15 & 38 \\
\hline 3.5 & 29.7 & L1 & 54.11 & 16 & 18 & 34 \\
\hline 3.6 & 30.0 & L1 & 63.78 & 31 & 29 & 60 \\
\hline 3.7 & 30.4 & L1 & 53.73 & 18 & 24 & 42 \\
\hline 3.8 & 30.8 & L1 & 57.77 & 38 & 28 & 66 \\
\hline 3.9 & 31.2 & L1 & 64.32 & 52 & 36 & 88 \\
\hline 4 & 31.5 & L1 & 61.03 & 53 & 42 & 95 \\
\hline 4.1 & 31.9 & L1 & 59.33 & 91 & 51 & 142 \\
\hline 4.2 & 32.3 & L1 & 57.51 & 69 & 28 & 97 \\
\hline 4.3 & 32.7 & L1 & 61.27 & 38 & 25 & 63 \\
\hline 4.4 & 33.1 & L1 & 61.00 & 26 & 26 & 52 \\
\hline 4.5 & 33.4 & L1 & 63.05 & 30 & 30 & 60 \\
\hline 4.6 & 33.8 & L1 & 66.17 & 33 & 33 & 66 \\
\hline 4.7 & 34.2 & L1 & 59.33 & 22 & 44 & 66 \\
\hline 4.8 & 35.1 & L1 & 65.20 & 21 & 48 & 69 \\
\hline 4.9 & 36.1 & L1 & 75.13 & 20 & 70 & 90 \\
\hline 5 & 36.6 & L1 & 71.00 & 20 & 51 & 71 \\
\hline 5.1 & 37.1 & L1 & 73.23 & 13 & 68 & 81 \\
\hline 5.2 & 37.6 & L1 & 67.84 & 26 & 60 & 86 \\
\hline 5.3 & 38.1 & L1 & 75.12 & 27 & 49 & 76 \\
\hline 5.4 & 38.6 & L1 & 72.16 & 33 & 37 & 70 \\
\hline
\end{tabular}




\begin{tabular}{|c|c|c|c|c|c|c|}
\hline 5.5 & 39.1 & L1 & 71.50 & 26 & 40 & 66 \\
\hline 5.6 & 39.6 & L1 & 72.40 & 16 & 44 & 60 \\
\hline 5.7 & 40.4 & L1 & 65.99 & 8 & 36 & 44 \\
\hline 5.8 & 41.1 & L1 & 63.73 & 9 & 15 & 24 \\
\hline 5.9 & 41.8 & L1 & 60.98 & 9 & 15 & 24 \\
\hline 6 & 42.5 & L1 & 67.33 & 3 & 16 & 19 \\
\hline 6.1 & 43.3 & L1 & 66.83 & 8 & 19 & 27 \\
\hline 6.2 & 44.0 & L1 & 67.01 & 10 & 11 & 21 \\
\hline 6.3 & 44.7 & L1 & 65.67 & 14 & 20 & 34 \\
\hline 6.4 & 45.4 & L1 & 64.95 & 22 & 21 & 43 \\
\hline 6.5 & 46.2 & L1 & 66.03 & 18 & 20 & 38 \\
\hline 6.6 & 46.9 & L1 & 72.95 & 24 & 74 & 98 \\
\hline 6.7 & 47.6 & L1 & 69.95 & 24 & 53 & 77 \\
\hline 6.8 & 48.3 & L1 & 71.29 & 9 & 68 & 77 \\
\hline 6.9 & 49.1 & L1 & 58.54 & 18 & 31 & 49 \\
\hline 7 & 49.4 & L1 & 60.10 & 11 & 35 & 46 \\
\hline 7.1 & 49.7 & L1 & 68.53 & 10 & 34 & 44 \\
\hline 7.2 & 50.0 & L1 & 68.23 & 4 & 31 & 35 \\
\hline 7.3 & 50.3 & L1 & 68.81 & 7 & 46 & 53 \\
\hline 7.4 & 50.7 & L1 & 70.71 & 8 & 37 & 45 \\
\hline 7.5 & 51.0 & L1 & 72.92 & 6 & 58 & 64 \\
\hline 7.6 & 51.3 & L1 & 75.86 & 5 & 63 & 68 \\
\hline 7.7 & 51.6 & L1 & 78.28 & 11 & 55 & 66 \\
\hline 7.8 & 51.9 & L1 & 81.41 & 6 & 62 & 68 \\
\hline 7.9 & 52.3 & L1 & 82.90 & 8 & 75 & 83 \\
\hline 8 & 52.6 & L1 & 88.89 & 11 & 43 & 54 \\
\hline 8.1 & 53.2 & L1 & 82.23 & 8 & 54 & 62 \\
\hline 8.2 & 53.9 & L1 & 80.10 & 19 & 61 & 80 \\
\hline 8.3 & 54.5 & L1 & 82.44 & 30 & 83 & 113 \\
\hline 8.4 & 55.2 & L1 & 78.43 & 18 & 49 & 67 \\
\hline 8.5 & 55.8 & L1 & 70.73 & 30 & 116 & 146 \\
\hline 8.6 & 56.5 & L1 & 69.50 & 35 & 139 & 174 \\
\hline 8.7 & 57.1 & L1 & 65.69 & 21 & 100 & 121 \\
\hline 8.8 & 57.7 & L1 & 50.72 & 51 & 142 & 193 \\
\hline 8.9 & 58.2 & L1 & 45.10 & 53 & 140 & 193 \\
\hline 9 & 58.6 & L1 & 42.64 & 73 & 130 & 203 \\
\hline 9.1 & 59.1 & L1 & 36.10 & 100 & 162 & 262 \\
\hline 9.2 & 59.5 & L1 & 39.18 & 132 & 194 & 326 \\
\hline 9.3 & 59.9 & L1 & 36.68 & 144 & 176 & 320 \\
\hline 9.4 & 60.3 & L1 & 38.38 & 132 & 187 & 319 \\
\hline 9.5 & 60.7 & L1 & 42.65 & 130 & 222 & 352 \\
\hline 9.6 & 61.1 & L1 & 36.18 & 111 & 243 & 354 \\
\hline
\end{tabular}




\begin{tabular}{|c|c|c|c|c|c|c|}
\hline 9.7 & 61.5 & L1 & 38.42 & 114 & 198 & 312 \\
\hline 9.8 & 61.9 & L1 & 37.81 & 120 & 221 & 341 \\
\hline 9.9 & 62.3 & L1 & 36.22 & 144 & 191 & 335 \\
\hline 10 & 62.7 & L1 & 35.61 & 80 & 89 & 169 \\
\hline 10.1 & 63.1 & L1 & 33.16 & 90 & 57 & 147 \\
\hline 10.2 & 63.5 & $\mathrm{~L} 1$ & 34.83 & 303 & 27 & 330 \\
\hline 10.3 & 63.9 & L1 & 35.68 & 283 & 10 & 293 \\
\hline 10.4 & 64.3 & L1 & 35.68 & 295 & 11 & 306 \\
\hline 10.5 & 64.7 & $\mathrm{~L} 1$ & 34.69 & 245 & 10 & 255 \\
\hline 10.6 & 65.1 & L1 & 33.33 & 225 & 14 & 239 \\
\hline 10.7 & 65.4 & L1 & 27.27 & 232 & 10 & 242 \\
\hline 10.8 & 65.8 & L1 & 30.46 & 276 & 18 & 294 \\
\hline 10.9 & 66.2 & $\mathrm{~L} 1$ & 37.24 & 232 & 12 & 244 \\
\hline 11 & 66.6 & L1 & 38.34 & 268 & 36 & 304 \\
\hline 11.1 & 67.0 & L1 & 30.00 & 206 & 30 & 236 \\
\hline 11.2 & 67.4 & L1 & 39.69 & 172 & 22 & 194 \\
\hline 11.3 & 67.8 & L1 & 37.31 & 108 & 38 & 146 \\
\hline 11.4 & 68.2 & L1 & 39.80 & 112 & 48 & 160 \\
\hline 11.5 & 68.6 & L1 & 44.95 & 137 & 68 & 205 \\
\hline 11.6 & 69.0 & L1 & 43.28 & 115 & 61 & 176 \\
\hline 11.7 & 69.4 & L1 & 39.49 & 59 & 56 & 115 \\
\hline 11.8 & 69.8 & L1 & 37.88 & 33 & 33 & 66 \\
\hline 11.9 & 70.2 & L1 & 37.76 & 14 & 12 & 26 \\
\hline 12 & 70.6 & L1 & 37.50 & 10 & 12 & 22 \\
\hline 12.1 & 71.0 & L1 & 58.59 & 15 & 34 & 49 \\
\hline 12.2 & 71.9 & S1 & 97.98 & 35 & 20 & 55 \\
\hline 12.3 & 72.8 & S1 & 117.59 & 1 & 4 & 5 \\
\hline 12.4 & 73.8 & S1 & 120.00 & 140 & 45 & 185 \\
\hline 12.5 & 79.4 & $\mathrm{~S} 1$ & 98.01 & 101 & 50 & 151 \\
\hline 12.6 & 85.0 & S1 & 116.92 & 211 & 50 & 261 \\
\hline 12.7 & 86.6 & S1 & 100.50 & 178 & 81 & 259 \\
\hline 12.8 & 88.3 & S1 & 114.36 & 131 & 68 & 199 \\
\hline 12.9 & 89.9 & S1 & 105.00 & 154 & 138 & 292 \\
\hline 13 & 91.6 & S1 & 110.45 & 140 & 154 & 294 \\
\hline 13.1 & 93.2 & S1 & 109.50 & 111 & 40 & 151 \\
\hline 13.2 & 94.9 & S1 & 132.16 & 229 & 122 & 351 \\
\hline 13.3 & 96.6 & S1 & 143.28 & 109 & 46 & 155 \\
\hline 13.4 & 98.9 & S1 & 134.00 & 112 & 71 & 183 \\
\hline 13.5 & 101.3 & S1 & 124.75 & 90 & 62 & 152 \\
\hline 13.6 & 103.5 & S1 & 128.36 & 72 & 60 & 132 \\
\hline 13.7 & 105.8 & S1 & 144.28 & 8 & 23 & 31 \\
\hline 13.8 & 108.0 & $\mathrm{~S} 1$ & 147.26 & 17 & 22 & 39 \\
\hline
\end{tabular}




\begin{tabular}{|c|c|c|c|c|c|c|}
\hline 13.9 & 110.2 & S1 & 149.49 & 13 & 21 & 34 \\
\hline 14 & 112.4 & S1 & 150.00 & 6 & 14 & 20 \\
\hline 14.1 & 114.4 & $\mathrm{~S} 1$ & 148.48 & 58 & 30 & 88 \\
\hline 14.2 & 116.3 & S1 & 147.26 & 7 & 4 & 11 \\
\hline 14.3 & 118.3 & S1 & 142.13 & 1 & 3 & 4 \\
\hline 14.4 & 120.2 & $\mathrm{~S} 1$ & 129.44 & 3 & 6 & 9 \\
\hline 14.5 & 122.2 & S1 & 121.50 & 1 & 9 & 10 \\
\hline 14.6 & 124.1 & $\mathrm{~S} 1$ & 101.49 & 16 & 6 & 22 \\
\hline 14.7 & 126.1 & S1 & 99.50 & 7 & 16 & 23 \\
\hline 14.8 & 128.0 & $\mathrm{~S} 1$ & 96.52 & 9 & 16 & 25 \\
\hline 14.9 & 130.0 & L2 & 77.78 & 13 & 15 & 28 \\
\hline 15 & 130.4 & L2 & 65.83 & 11 & 19 & 30 \\
\hline 15.1 & 130.8 & $\mathrm{~L} 2$ & 61.58 & 19 & 37 & 56 \\
\hline 15.2 & 131.1 & $\mathrm{~L} 2$ & 41.71 & 9 & 30 & 39 \\
\hline 15.3 & 131.5 & L2 & 34.48 & 24 & 32 & 56 \\
\hline 15.4 & 131.9 & L2 & 31.19 & 39 & 23 & 62 \\
\hline 15.5 & 133.2 & L2 & 48.00 & 42 & 40 & 82 \\
\hline 15.6 & 134.4 & L2 & 32.50 & 79 & 99 & 178 \\
\hline 15.7 & 135.7 & L2 & 30.00 & 80 & 104 & 184 \\
\hline 15.8 & 136.9 & L2 & 32.00 & 153 & 106 & 259 \\
\hline 15.9 & 138.2 & L2 & 32.00 & 205 & 178 & 383 \\
\hline 16 & 139.4 & L2 & 33.00 & 203 & 198 & 401 \\
\hline 16.1 & 140.7 & L2 & 33.17 & 203 & 219 & 422 \\
\hline 16.2 & 141.9 & L2 & 32.66 & 163 & 180 & 343 \\
\hline 16.3 & 143.2 & L2 & 35.35 & 193 & 209 & 402 \\
\hline 16.4 & 144.4 & L2 & 33.83 & 272 & 248 & 520 \\
\hline 16.5 & 145.7 & L2 & 37.44 & 174 & 253 & 427 \\
\hline 16.6 & 146.9 & L2 & 37.37 & 194 & 261 & 455 \\
\hline 16.7 & 148.2 & L2 & 37.50 & 126 & 379 & 505 \\
\hline 16.8 & 149.4 & L2 & 41.00 & 145 & 217 & 362 \\
\hline 16.9 & 150.2 & L2 & 39.49 & 148 & 208 & 356 \\
\hline 17 & 150.9 & L2 & 38.78 & 76 & 192 & 268 \\
\hline 17.1 & 151.6 & L2 & 32.99 & 78 & 108 & 186 \\
\hline 17.2 & 152.3 & L2 & 35.68 & 46 & 54 & 100 \\
\hline 17.3 & 153.1 & L2 & 34.02 & 69 & 44 & 113 \\
\hline 17.4 & 153.8 & $\mathrm{~L} 2$ & 35.00 & 62 & 43 & 105 \\
\hline 17.5 & 154.5 & L2 & 34.50 & 152 & 30 & 182 \\
\hline 17.6 & 155.3 & L2 & 33.33 & 182 & 11 & 193 \\
\hline 17.7 & 156.0 & L2 & 31.98 & 193 & 17 & 210 \\
\hline 17.8 & 156.7 & L2 & 28.64 & 209 & 7 & 216 \\
\hline 17.9 & 157.4 & L2 & 30.65 & 254 & 11 & 265 \\
\hline 18 & 158.2 & L2 & 31.86 & 246 & 4 & 250 \\
\hline
\end{tabular}




\begin{tabular}{|c|c|c|c|c|c|c|}
\hline 18.1 & 158.9 & L2 & 32.02 & 369 & 27 & 396 \\
\hline 18.2 & 159.6 & $\mathrm{~L} 2$ & 31.66 & 343 & 12 & 355 \\
\hline 18.3 & 160.4 & L2 & 39.50 & 212 & 11 & 223 \\
\hline 18.4 & 161.2 & L2 & 32.18 & 116 & 14 & 130 \\
\hline 18.5 & 162.1 & $\mathrm{~L} 2$ & 29.44 & 129 & 26 & 155 \\
\hline 18.6 & 162.9 & L2 & 29.56 & 120 & 13 & 133 \\
\hline 18.7 & 163.8 & L2 & 31.09 & 90 & 38 & 128 \\
\hline 18.8 & 164.6 & $\mathrm{~L} 2$ & 32.49 & 40 & 26 & 66 \\
\hline 18.9 & 165.5 & $\mathrm{~L} 2$ & 37.82 & 35 & 39 & 74 \\
\hline 19 & 166.3 & L2 & 42.86 & 7 & 58 & 65 \\
\hline 19.1 & 167.2 & L2 & 43.88 & 16 & 42 & 58 \\
\hline 19.2 & 168.0 & $\mathrm{~L} 2$ & 52.45 & 30 & 79 & 109 \\
\hline 19.3 & 168.9 & L2 & 51.02 & 27 & 53 & 80 \\
\hline 19.4 & 170.7 & L2 & 49.74 & 30 & 68 & 98 \\
\hline 19.5 & 172.5 & L2 & 46.50 & 42 & 95 & 137 \\
\hline 19.6 & 174.3 & L2 & 46.00 & 50 & 84 & 134 \\
\hline 19.7 & 176.1 & L2 & 41.00 & 66 & 79 & 145 \\
\hline 19.8 & 177.9 & L2 & 41.00 & 48 & 76 & 124 \\
\hline 19.9 & 179.7 & $\mathrm{~L} 2$ & 43.00 & 104 & 93 & 197 \\
\hline 20 & 181.5 & $\mathrm{~L} 2$ & 38.00 & 134 & 127 & 261 \\
\hline 20.1 & 183.3 & L2 & 37.31 & 129 & 156 & 285 \\
\hline 20.2 & 184.1 & $\mathrm{~L} 2$ & 40.30 & 256 & 281 & 537 \\
\hline 20.3 & 185.0 & L2 & 52.97 & 415 & 309 & 724 \\
\hline 20.4 & 185.9 & L2 & 56.44 & 553 & 510 & 1063 \\
\hline 20.5 & 186.7 & L2 & 61.69 & 561 & 568 & 1129 \\
\hline 20.6 & 187.6 & $\mathrm{~L} 2$ & 62.69 & 413 & 483 & 896 \\
\hline 20.7 & 188.4 & $\mathrm{~L} 2$ & 62.50 & 401 & 244 & 645 \\
\hline 20.8 & 189.3 & L2 & 66.00 & 546 & 176 & 722 \\
\hline 20.9 & 190.1 & $\mathrm{~L} 2$ & 73.63 & 680 & 243 & 923 \\
\hline 21 & 191.0 & L2 & 83.00 & 759 & 238 & 997 \\
\hline
\end{tabular}


Table S2. Dataset of the number of Vallonia tenera and Pupilla aeoli (VP) individuals in loess units L2 and L1 from the Luochuan section.

\begin{tabular}{|c|c|c|c|c|c|c|}
\hline Depth (m) & Age (ka) & Lithology & $\begin{array}{c}\text { Magnetic } \\
\text { susceptibility }\end{array}$ & $\begin{array}{c}\text { Vallonia } \\
\text { tenera }\end{array}$ & $\begin{array}{c}\text { Pupilla } \\
\text { aeoli }\end{array}$ & VP \\
\hline 1.5 & 11.7 & L1 & 41.10 & 1 & 0 & 1 \\
\hline 1.6 & 12.9 & $\mathrm{~L} 1$ & 41.80 & 2 & 1 & 3 \\
\hline 1.7 & 14.1 & L1 & 34.80 & 1 & 0 & 1 \\
\hline 1.8 & 15.3 & L1 & 37.10 & 0 & 3 & 3 \\
\hline 1.9 & 16.5 & L1 & 30.70 & 1 & 2 & 3 \\
\hline 2 & 17.7 & L1 & 32.80 & 1 & 2 & 3 \\
\hline 2.1 & 18.9 & L1 & 32.40 & 0 & 2 & 2 \\
\hline 2.2 & 20.1 & L1 & 34.10 & 2 & 2 & 4 \\
\hline 2.3 & 21.3 & $\mathrm{L1}$ & 32.50 & 0 & 0 & 0 \\
\hline 2.4 & 22.5 & L1 & 34.00 & 3 & 1 & 4 \\
\hline 2.5 & 23.7 & $\mathrm{~L} 1$ & 33.40 & 5 & 1 & 6 \\
\hline 2.6 & 24.9 & L1 & 34.50 & 6 & 4 & 10 \\
\hline 2.7 & 26.1 & L1 & 39.10 & 2 & 6 & 8 \\
\hline 2.8 & 27.3 & L1 & 42.70 & 3 & 7 & 10 \\
\hline 2.9 & 28.5 & L1 & 39.70 & 5 & 11 & 16 \\
\hline 3 & 29.7 & $\mathrm{~L} 1$ & 47.60 & 5 & 7 & 12 \\
\hline 3.1 & 30.3 & L1 & 49.00 & 12 & 4 & 16 \\
\hline 3.2 & 31.0 & L1 & 51.20 & 8 & 17 & 25 \\
\hline 3.3 & 31.6 & L1 & 52.70 & 17 & 9 & 26 \\
\hline 3.4 & 32.2 & L1 & 52.20 & 25 & 30 & 55 \\
\hline 3.5 & 32.9 & L1 & 52.00 & 23 & 26 & 49 \\
\hline 3.6 & 33.5 & L1 & 52.10 & 27 & 13 & 40 \\
\hline 3.7 & 34.2 & $\mathrm{~L} 1$ & 53.20 & 18 & 21 & 39 \\
\hline 3.8 & 34.6 & L1 & 60.70 & 1 & 21 & 22 \\
\hline 3.9 & 34.9 & L1 & 65.50 & 6 & 20 & 26 \\
\hline 4 & 35.3 & L1 & 66.10 & 2 & 16 & 18 \\
\hline 4.1 & 35.7 & L1 & 65.90 & 4 & 30 & 34 \\
\hline 4.2 & 36.1 & L1 & 70.80 & 8 & 27 & 35 \\
\hline 4.3 & 36.7 & L1 & 70.50 & 16 & 3 & 19 \\
\hline 4.4 & 37.3 & L1 & 69.00 & 40 & 6 & 46 \\
\hline 4.5 & 37.9 & L1 & 70.80 & 15 & 15 & 30 \\
\hline 4.6 & 38.4 & L1 & 66.90 & 3 & 36 & 39 \\
\hline 4.7 & 39.0 & L1 & 67.90 & 8 & 51 & 59 \\
\hline 4.8 & 39.6 & L1 & 68.20 & 6 & 71 & 77 \\
\hline 4.9 & 40.6 & L1 & 73.70 & 1 & 47 & 48 \\
\hline
\end{tabular}




\begin{tabular}{|c|c|c|c|c|c|c|}
\hline 5 & 41.5 & L1 & 69.90 & 6 & 67 & 73 \\
\hline 5.1 & 42.5 & L1 & 70.90 & 10 & 64 & 74 \\
\hline 5.2 & 43.4 & L1 & 68.40 & 12 & 54 & 66 \\
\hline 5.3 & 44.3 & L1 & 67.60 & 9 & 50 & 59 \\
\hline 5.4 & 45.3 & L1 & 67.70 & 28 & 50 & 78 \\
\hline 5.5 & 46.2 & L1 & 66.50 & 16 & 35 & 51 \\
\hline 5.6 & 47.2 & L1 & 67.20 & 22 & 35 & 57 \\
\hline 5.7 & 48.1 & L1 & 68.80 & 22 & 43 & 65 \\
\hline 5.8 & 49.1 & $\mathrm{~L} 1$ & 60.00 & 18 & 50 & 68 \\
\hline 5.9 & 49.4 & L1 & 62.70 & 23 & 47 & 70 \\
\hline 6 & 49.8 & L1 & 72.90 & 29 & 62 & 91 \\
\hline 6.1 & 50.1 & L1 & 69.60 & 43 & 78 & 121 \\
\hline 6.2 & 50.5 & $\mathrm{~L} 1$ & 72.40 & 42 & 62 & 104 \\
\hline 6.3 & 50.8 & L1 & 69.00 & 30 & 62 & 92 \\
\hline 6.4 & 51.2 & L1 & 75.40 & 10 & 73 & 83 \\
\hline 6.5 & 51.5 & L1 & 80.10 & 4 & 90 & 94 \\
\hline 6.6 & 51.9 & L1 & 75.70 & 12 & 86 & 98 \\
\hline 6.7 & 52.2 & L1 & 83.10 & 4 & 75 & 79 \\
\hline 6.8 & 52.6 & L1 & 88.10 & 7 & 67 & 74 \\
\hline 6.9 & 53.0 & L1 & 81.30 & 2 & 62 & 64 \\
\hline 7 & 53.4 & L1 & 78.70 & 2 & 74 & 76 \\
\hline 7.1 & 53.9 & L1 & 69.90 & 0 & 81 & 81 \\
\hline 7.2 & 54.3 & L1 & 64.10 & 0 & 98 & 98 \\
\hline 7.3 & 54.7 & L1 & 65.60 & 7 & 119 & 126 \\
\hline 7.4 & 55.2 & L1 & 65.50 & 27 & 132 & 159 \\
\hline 7.5 & 55.6 & L1 & 66.20 & 10 & 79 & 89 \\
\hline 7.6 & 56.0 & L1 & 62.80 & 9 & 101 & 110 \\
\hline 7.7 & 56.5 & L1 & 53.80 & 34 & 93 & 127 \\
\hline 7.8 & 56.9 & L1 & 55.40 & 38 & 147 & 185 \\
\hline 7.9 & 57.3 & L1 & 55.80 & 59 & 205 & 264 \\
\hline 8 & 57.7 & L1 & 49.10 & 63 & 189 & 252 \\
\hline 8.1 & 59.1 & L1 & 33.30 & 92 & 214 & 306 \\
\hline 8.2 & 59.8 & L1 & 33.80 & 195 & 270 & 465 \\
\hline 8.3 & 60.4 & L1 & 33.90 & 95 & 156 & 251 \\
\hline 8.4 & 61.1 & L1 & 34.80 & 77 & 104 & 181 \\
\hline 8.5 & 61.7 & L1 & 31.60 & 109 & 110 & 219 \\
\hline 8.6 & 62.4 & L1 & 31.40 & 72 & 55 & 127 \\
\hline 8.7 & 63.1 & $\mathrm{~L} 1$ & 34.60 & 43 & 46 & 89 \\
\hline 8.8 & 63.7 & $\mathrm{~L} 1$ & 37.20 & 225 & 195 & 420 \\
\hline 8.9 & 64.4 & L1 & 34.40 & 181 & 166 & 347 \\
\hline 9 & 65.1 & L1 & 36.00 & 216 & 227 & 443 \\
\hline 9.1 & 65.7 & L1 & 37.80 & 114 & 226 & 340 \\
\hline
\end{tabular}




\begin{tabular}{|c|c|c|c|c|c|c|}
\hline 9.2 & 66.4 & L1 & 38.40 & 242 & 241 & 483 \\
\hline 9.3 & 67.0 & L1 & 37.30 & 142 & 105 & 247 \\
\hline 9.4 & 67.7 & L1 & 37.50 & 155 & 154 & 309 \\
\hline 9.5 & 68.4 & L1 & 43.50 & 88 & 122 & 210 \\
\hline 9.6 & 69.0 & L1 & 41.40 & 89 & 126 & 215 \\
\hline 9.7 & 69.7 & $\mathrm{~L} 1$ & 48.20 & 117 & 117 & 234 \\
\hline 9.8 & 70.3 & L1 & 50.80 & 110 & 107 & 217 \\
\hline 9.9 & 71.0 & L1 & 71.30 & 64 & 17 & 81 \\
\hline 10 & 72.4 & S1 & 73.70 & 41 & 32 & 73 \\
\hline 10.1 & 73.8 & $\mathrm{~S} 1$ & 129.30 & 22 & 16 & 38 \\
\hline 10.2 & 85.0 & S1 & 104.50 & 12 & 11 & 23 \\
\hline 10.3 & 90.8 & S1 & 111.40 & 6 & 20 & 26 \\
\hline 10.4 & 96.6 & $\mathrm{~S} 1$ & 128.30 & 9 & 33 & 42 \\
\hline 10.5 & 98.9 & $\mathrm{~S} 1$ & 114.40 & 22 & 23 & 45 \\
\hline 10.6 & 101.3 & S1 & 105.80 & 25 & 31 & 56 \\
\hline 10.7 & 103.2 & S1 & 131.60 & 41 & 17 & 58 \\
\hline 10.8 & 105.0 & $\mathrm{~S} 1$ & 132.80 & 63 & 32 & 95 \\
\hline 10.9 & 106.9 & S1 & 161.40 & 28 & 12 & 40 \\
\hline 11 & 108.7 & S1 & 170.80 & 18 & 11 & 29 \\
\hline 11.1 & 110.6 & S1 & 168.00 & 5 & 4 & 9 \\
\hline 11.2 & 112.4 & S1 & 180.30 & 0 & 0 & 0 \\
\hline 11.3 & 115.4 & $\mathrm{~S} 1$ & 171.20 & 4 & 0 & 4 \\
\hline 11.4 & 118.3 & S1 & 165.60 & 3 & 1 & 4 \\
\hline 11.5 & 121.2 & S1 & 154.20 & 0 & 0 & 0 \\
\hline 11.6 & 124.1 & S1 & 122.70 & 0 & 0 & 0 \\
\hline 11.7 & 127.1 & S1 & 97.50 & 0 & 0 & 0 \\
\hline 11.8 & 130.0 & L2 & 74.90 & 0 & 0 & 0 \\
\hline 11.9 & 131.9 & L2 & 23.30 & 18 & 34 & 52 \\
\hline 12 & 132.9 & L2 & 25.20 & 31 & 44 & 75 \\
\hline 12.1 & 134.0 & L2 & 24.40 & 60 & 121 & 181 \\
\hline 12.2 & 135.0 & L2 & 21.50 & 68 & 122 & 190 \\
\hline 12.3 & 136.0 & L2 & 24.40 & 107 & 190 & 297 \\
\hline 12.4 & 137.1 & L2 & 24.70 & 197 & 213 & 410 \\
\hline 12.5 & 138.1 & L2 & 25.10 & 169 & 293 & 462 \\
\hline 12.6 & 139.1 & L2 & 27.10 & 226 & 284 & 510 \\
\hline 12.7 & 140.2 & L2 & 29.20 & 227 & 253 & 480 \\
\hline 12.8 & 141.2 & L2 & 31.80 & 194 & 249 & 443 \\
\hline 12.9 & 142.2 & L2 & 32.10 & 217 & 333 & 550 \\
\hline 13 & 143.3 & L2 & 33.00 & 197 & 314 & 511 \\
\hline 13.1 & 144.3 & L2 & 33.80 & 185 & 352 & 537 \\
\hline 13.2 & 145.3 & L2 & 33.80 & 269 & 288 & 557 \\
\hline 13.3 & 146.3 & $\mathrm{~L} 2$ & 36.10 & 213 & 316 & 529 \\
\hline
\end{tabular}




\begin{tabular}{|c|c|c|c|c|c|c|}
\hline 13.4 & 147.4 & $\mathrm{~L} 2$ & 34.70 & 136 & 244 & 380 \\
\hline 13.5 & 148.4 & $\mathrm{~L} 2$ & 34.70 & 183 & 208 & 391 \\
\hline 13.6 & 149.4 & $\mathrm{~L} 2$ & 36.10 & 176 & 172 & 348 \\
\hline 13.7 & 150.4 & $\mathrm{~L} 2$ & 33.70 & 173 & 161 & 334 \\
\hline 13.8 & 151.4 & $\mathrm{~L} 2$ & 30.00 & 210 & 96 & 306 \\
\hline 13.9 & 152.4 & $\mathrm{~L} 2$ & 30.20 & 131 & 43 & 174 \\
\hline 14 & 153.4 & $\mathrm{~L} 2$ & 30.70 & 145 & 64 & 209 \\
\hline 14.1 & 154.4 & $\mathrm{~L} 2$ & 27.50 & 153 & 40 & 193 \\
\hline 14.2 & 155.4 & $\mathrm{~L} 2$ & 25.60 & 84 & 84 & 168 \\
\hline 14.3 & 156.4 & $\mathrm{~L} 2$ & 27.00 & 77 & 62 & 139 \\
\hline 14.4 & 157.4 & $\mathrm{~L} 2$ & 24.00 & 55 & 21 & 76 \\
\hline 14.5 & 158.4 & $\mathrm{~L} 2$ & 23.10 & 54 & 25 & 79 \\
\hline 14.6 & 159.4 & $\mathrm{~L} 2$ & 24.50 & 78 & 23 & 101 \\
\hline 14.7 & 160.4 & L2 & 30.30 & 98 & 25 & 123 \\
\hline 14.8 & 161.6 & $\mathrm{~L} 2$ & 30.20 & 88 & 24 & 112 \\
\hline 14.9 & 162.8 & L2 & 32.50 & 65 & 18 & 83 \\
\hline 15 & 164.0 & $\mathrm{~L} 2$ & 41.40 & 48 & 29 & 77 \\
\hline 15.1 & 165.2 & L2 & 53.60 & 29 & 170 & 199 \\
\hline 15.2 & 166.4 & $\mathrm{~L} 2$ & 60.50 & 44 & 53 & 97 \\
\hline 15.3 & 167.7 & $\mathrm{~L} 2$ & 71.60 & 31 & 38 & 69 \\
\hline 15.4 & 168.9 & $\mathrm{~L} 2$ & 72.80 & 29 & 64 & 93 \\
\hline 15.5 & 170.3 & $\mathrm{~L} 2$ & 59.10 & 16 & 43 & 59 \\
\hline 15.6 & 171.8 & $\mathrm{~L} 2$ & 68.20 & 25 & 103 & 128 \\
\hline 15.7 & 173.2 & $\mathrm{~L} 2$ & 68.90 & 36 & 138 & 174 \\
\hline 15.8 & 174.6 & $\mathrm{~L} 2$ & 64.70 & 31 & 70 & 101 \\
\hline 15.9 & 176.1 & $\mathrm{~L} 2$ & 51.50 & 65 & 93 & 158 \\
\hline 16 & 177.5 & $\mathrm{~L} 2$ & 43.30 & 125 & 88 & 213 \\
\hline 16.1 & 179.0 & $\mathrm{~L} 2$ & 39.10 & 154 & 57 & 211 \\
\hline 16.2 & 180.4 & $\mathrm{~L} 2$ & 35.60 & 130 & 93 & 223 \\
\hline 16.3 & 181.8 & $\mathrm{~L} 2$ & 35.20 & 122 & 84 & 206 \\
\hline 16.4 & 183.3 & $\mathrm{~L} 2$ & 33.70 & 113 & 99 & 212 \\
\hline 16.5 & 184.2 & $\mathrm{~L} 2$ & 38.20 & 153 & 148 & 301 \\
\hline 16.6 & 185.2 & $\mathrm{~L} 2$ & 43.40 & 116 & 139 & 255 \\
\hline 16.7 & 186.2 & $\mathrm{~L} 2$ & 46.20 & 202 & 218 & 420 \\
\hline 16.8 & 187.1 & $\mathrm{~L} 2$ & 52.80 & 268 & 188 & 456 \\
\hline 16.9 & 188.1 & L2 & 56.00 & 273 & 229 & 502 \\
\hline 17 & 189.1 & $\mathrm{~L} 2$ & 61.40 & 469 & 308 & 777 \\
\hline 17.1 & 190.0 & $\mathrm{~L} 2$ & 74.80 & 55 & 19 & 74 \\
\hline 17.2 & 191.0 & $\mathrm{~L} 2$ & 82.50 & 415 & 204 & 619 \\
\hline
\end{tabular}

